\title{
Trade-Liberalization Strategies: What Could Southeastern Europe Learn from the CEFTA and BFTA?
}

Antonis Adam, Theodora S. Kosma, and

Jimmy McHugh 


\title{
IMF Working Paper
}

\author{
European Department
}

\section{Trade-Liberalization Strategies: What Could Southeastern Europe Learn from CEFTA and BFTA?}

\author{
Prepared by Antonis Adam, Theodora S. Kosma, and Jimmy McHugh ${ }^{1}$ \\ Authorized for distribution by David Owen
}

December 2003

\begin{abstract}
This Working Paper should not be reported as representing views of the IMF. The views expressed in this Working Paper are those of the author(s) and do not necessarily represent those of the IMF or IMF policy. Working Papers describe research in progress by the author(s) and are published to elicit comments and to further debate.
\end{abstract}

This paper explores the effectiveness of the Central European Free Trade Area (CEFTA) and the Baltic Free Trade Area (BFTA). Estimates from a gravity model and bilateral trade data support the view that both CEFTA and BFTA helped expand regional trade and limit the emergence of a "hub-and-spoke" relationship between the CEECs and the European Union (EU). These empirical conclusions carry some important policy implications for the "second wave" of prospective EU members among Southeastern European Countries (SEECs). The paper argues that the SEECs should reconsider their bilateral approach to trade liberalization and move towards a multilateral free-trade area as exemplified by both the CEFTA and BFTA.

JEL Classification Numbers: F15, F13, C23, P5

Keywords: Trade liberalization, gravity models, stability pact, CEFTA, BFTA

Authors’ E-Mail Addresses: aadam@aueb.gr; kosma@aueb.gr; jmchugh@,imf.org

\footnotetext{
${ }^{1}$ Antonis Adam and Theodora Kosma are students in the Department of International and European Economic Studies (DIEES), at Athens University of Economics and Business (AUEB), 76 Patission Street, 10434, Athens, Greece. Jimmy McHugh is the IMF's Resident Representative in Armenia. The authors would like to thank Gohar Minasyan for research assistance. For helpful comments and suggestions, they would like to thank John Zorhab, T. Moutos, P. Hatzipanayotou, and S. Brissimis. They would also like to thank the participants in the IMF European I Department seminar, held in June 2003, and the participants in the ETSG 2003 conference held in September 2003, for their numerous helpful comments and suggestions. All errors remain the responsibility of the authors.
} 


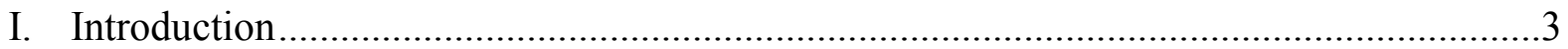

II. Trade Liberalization in Central and Eastern European Countries ..................................4

III. Trade Liberalization in Southeastern European Countries ............................................. 7

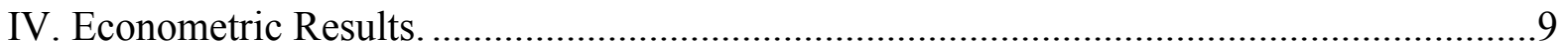

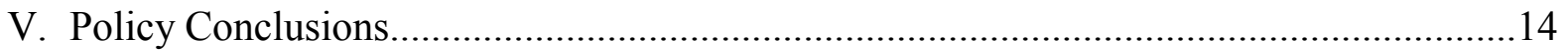

Appendix

I. Description of Two-Step, Fixed-Effect Estimation Method...........................................16

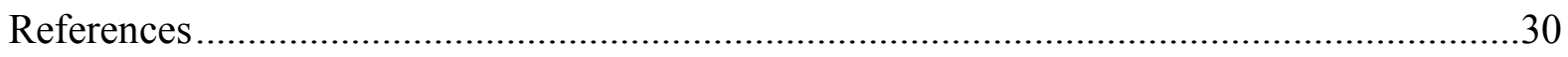

Tables

1. Central and Eastern Europe: Total Exports, 1993-2001 ........................................ 18

2. Central and Eastern Europe: Exports to European Union (EU), 1993-2001 ................. 19

3. Central and Eastern Europe: Market Share of EU Imports, 1993-2001......................... 20

4. Central and Eastern Europe: Exports to Central European Free Trade Area (CEFTA)

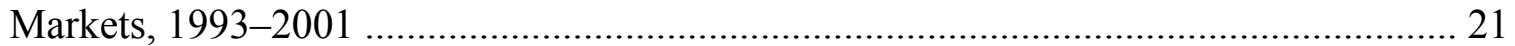

5. Central and Eastern Europe: Market Share of CEFTA Countries' Imports,

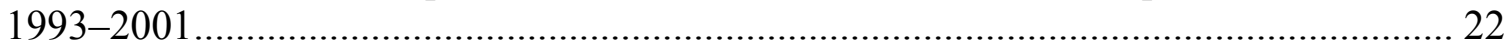

6. Central and Eastern Europe: Exports to Baltic Free Trade Area (BFTA)

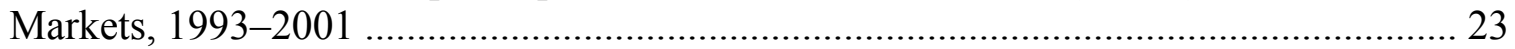

7. Central and Eastern Europe: Market Share in BFTA Countries' Imports, 1993-2001 ... 24

8. Central and Eastern Europe: Exports to European Union (EU), 1993-2001 .................. 25

9. Central and Eastern Europe: Exports to Southeastern European (SEE) Markets,

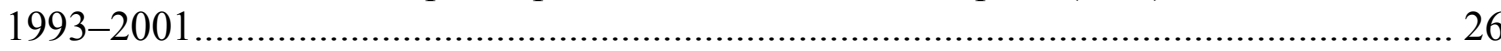

10. Southeastern Europe: Status of June 2002 Memorandum of Understanding on Bilateral

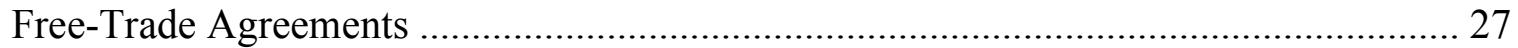

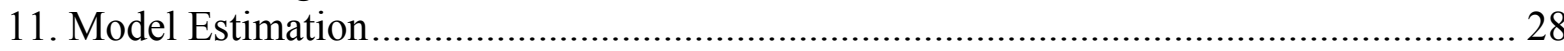

Figures

1. Cross-Sectional Estimated Parameter Values for Trade Agreements, 1996-2000.......... 29 


\title{
I. INTRODUCTION
}

\begin{abstract}
During the early 1990s, the Central and Eastern European Countries (CEECs) ${ }^{2}$ created two free-trade agreements known as the Central European Free Trade Area (CEFTA) and the Baltic Free Trade Area (BFTA). Both agreements were created in response to a perceived weakness in the case for the eastern enlargement of the European Union (EU). The EU member states were initially skeptical about the CEECs' ability to cope with the cooperative and multilateral structures of the EU. Furthermore, there was an understandable fear that the EU accession process would redirect CEEC exports towards the EU and therefore render the CEECs more vulnerable to adverse shocks coming from the EU (Baldwin, 1993, 1994, 1995). Thus, the CEFTA and BFTA had two objectives. First, they were an early and important test of the CEECs' capacity to work together within cooperative trade arrangements. Second, they hoped to counter the growing dependence of the CEECs on EU markets by re-establishing regional trade flows.
\end{abstract}

How effective were the CEFTA and BFTA in achieving these two objectives? In terms of the first objective, this paper offers a generally positive assessment. Throughout the 1990s, both the CEFTA and BFTA became the main vehicles for regional trade liberalization. From an original membership of three, the CEFTA gradually enlarged to cover most of Central Europe. Although BFTA membership did not increase, the agreement was gradually expanded to cover a number of the politically sensitive areas, including agriculture and fisheries. However, the agreements had only a limited effect on reducing the CEECs' dependence on the EU. In regard to their impact on trade flows, estimates from our gravity model show that both arrangements had a positive effect on regional bilateral trade. Furthermore, intraregional trade increased and complemented the rapid increase in trade with the EU. Intraregional market shares held up well within CEFTA and actually increased in BFTA. Yet despite their success in promoting regional trade, the EU remained the dominant trading partner for the CEECs.

\footnotetext{
What lessons could the Southeastern European Countries (SEECs) ${ }^{3}$ learn from the experiences of the CEFTA and BFTA? In contrast to their northern neighbors, the SEECs did little during the 1990s to foster regional trade integration. Unsurprisingly, their export performance throughout the decade was extremely disappointing. Obviously, a large part of the explanation lies in the horrific conflicts that plagued the region throughout the decade which, along with the terrible humanitarian consequences, limited regional integration. These conflicts subsided after the 1999 Kosovo crisis; and, since then, the SEECs have tried to

${ }^{2}$ For the purposes of this paper, the CEECs include the following countries: Bulgaria, the Czech Republic, Estonia, Hungary, Latvia, Lithuania, Poland, Romania, the Slovak Republic, and Slovenia. The CEFTA originated in the Visegrad countries - Czechoslovakia, Poland, and Hungary. It was later enlarged to include Romania, Bulgaria, and Slovenia, as well as the successor states to Czechoslovakia. More recently, Croatia has joined, becoming the only member that was not an EU candidate country. As the name suggests, the Baltic states of Estonia, Latvia, and Lithuania were the three members of the BFTA.

${ }^{3}$ The SEECs include Albania, Bosnia and Herzegovina, Croatia, FYR of Macedonia, and Serbia and Montenegro.
} 
reinvigorate regional trade integration. However, for a variety of political reasons, the SEECs did not take a multilateral approach. Instead, they started to negotiate a network of bilateral free-trade agreements in the hope of creating a "virtual" regional free-trade area. This project is nearly completed. Although it is still too early to tell how successful this bilateral approach will be, it is fairly clear that the approach has some severe limitations, which may curb further trade reform in the future.

In the light of the CEECs' experience, this paper strongly argues that the SEECs should reexamine their trade-liberalization strategy and adopt a more multilateral approach. The SEECs are now in the same approximate position as the CEECs were during the early 1990s. Through the Stability and Association Agreements, the EU is offering the SEECs highly preferential trade agreements and the possibility of EU accession. Yet the EU member states have serious doubts about the SEECs' capacity to build sustainable and peaceful economic and political relations with their neighbors. Greater regional integration could provide a valuable test for the SEECs and demonstrate that they are capable of sustaining a closer political and economic relationship with the rest of Europe.

There are three options available to the SEECs to develop regional integration. First, the CEFTA could be enlarged to include the SEECs. Second, the current system of bilateral free-trade arrangements could be harmonized and developed further to cover difficult trade issues such as agriculture, services, and "behind-the-border" issues like public procurement. Third, the SEECs could develop their own comprehensive multilateral free-trade agreement along the lines of the CEFTA and BFTA. Overall, we believe that a new multilateral free-trade agreement — the South East European Free Trade Area-is the most viable.

\section{Trade Liberalization in Central and Eastern European Countries}

During the early stages of transition, the CEECs moved quickly to liberalize their trade and exchange regimes. The newly democratized countries quickly discarded the old Soviet-led trade agreement, the Council for Mutual Economic Assistance (CMEA). International trade was conducted at world prices and settled in convertible currencies. Tariff rates were lowered. Furthermore, the CEECs removed the plethora of restrictions that had characterized trade in the socialist economies; import and export controls were abolished, licensing regimes were liberalized, and foreign direct investment was permitted. However, these reforms were initially accompanied by a dramatic short-term collapse in regional trade flows.

While the transition led to a sharp fall in regional trade, it had also opened up the possibility of EU accession. However, the EU member states were wary of the idea of an eastern enlargement. The EU member states felt that it would take a considerable length of time before the CEECs had reached a sufficient level of economic and political development to ensure that enlargement would be a success. The EU member states were also worried that the newly democratized governments lacked experience of closely cooperating with their neighbors on economic and trade issues. Therefore, the EU pushed hard for the CEEC countries to establish closer political and economic relationships as a precursor to EU enlargement (for a discussion see Richter, 1998). 
The CEECs responded quickly to the EU's challenge. They initiated a variety of economic, political, and diplomatic initiatives to enhance regional cooperation. The region took particular note of the EU's stress on re-establishing regional trade flows. Both the Visegrad and Baltic countries started discussions on creating regional free-trade agreements. In December 1992, Hungary, Poland, and Czechoslovakia signed the Central European Free Trade Agreement (CEFTA). ${ }^{4}$ The original members envisaged the creation of a free-trade area by 2001. The Baltic States launched their Free Trade Agreement slightly later than the CEFTA. They signed the BFTA in 1993, and it took effect in April 1994.

Despite its early reluctance, by the mid-1990s the EU had formulated a road map for the eastern enlargement. In particular, the EU developed an institutional mechanism for preparing CEEC candidate countries for EU membership - the Europe Agreements. These agreements provided for closer political and economic cooperation with the EU. They also specified a timetable for tariff reductions and prepared the candidate countries for accession through technical assistance, legal approximation to the acquis communitaire, and financial assistance.

\section{However, asymmetric trade-liberalization was the main innovation of the Europe Agreements. The EU member states would eliminate trade restrictions faster than the candidate countries. Notwithstanding these generally favorable terms, a number of sensitive areas, such as agriculture and textiles, were exempt from the agreements. In general, these were sectors in which the CEECs had comparative advantages (for a discussion of this issue, see Lavigne, 1995). ${ }^{5}$ Nevertheless, these agreements were beneficial for the CEECs, and both EU trade and foreign direct investment increased rapidly.}

However, the Europe Agreements suffered from a serious weakness; they did nothing to encourage and foster intra-CEEC trade. Many economists quickly recognized that asymmetric liberalization could create a "hub-and-spoke" problem (see Baldwin 1994). The Europe Agreements would divert trade flows along a "spoke" between the CEECs and the "hub" comprising of the EU member states. The CEECs would become satellite economies orbiting around the EU, with little intraregional trade. This raised the danger that, as trade became increasingly centered on the EU, the CEECs would become vulnerable to adverse shocks from the EU. Furthermore, there was an additional fear that the lack of intraregional trade-liberalization would tend to restrict intra-CEEC competition.

Ultimately, these hub-and-spoke considerations may have forced the CEEC countries to accelerate their plans to develop regional trade integration. As more CEEC countries signed Europe Agreements, it became increasingly clear that the EU enlargement would

\footnotetext{
${ }^{4}$ For a survey of the post-transition decline of CMEA trade and the creation of the CEFTA see Rudka and Mizsei (1994).

${ }^{5}$ For a complete discussion of the impact of EU accession on both the EU member states and the CEECs see Baldwin and others (1997), and Adam and Moutos (2002).
} 
incorporate the majority of eastern European countries. The CEFTA was progressively enlarged to include Romania, Bulgaria, and Slovenia. The Czech Republic and Slovakia automatically became members as successor states to Czechoslovakia. Throughout the 1990s, the coverage of both agreements were progressively expanded. The original CEFTA agreement eliminated duties on approximately 40 percent of industrial goods. Through a series of additional protocols, mostly signed in 1994 and 1995, trade in industrial goods and some agricultural products was further liberalized. By 1997, the CEFTA had abolished duties on all industrial goods, apart from a minor list of sensitive goods. The BFTA did not increase its membership, but the coverage of the agreement was expanded. The Baltic States had always intended to include agriculture and fish products. However, extending the agreement proved more difficult than anticipated, largely because financial support for agriculture was more significant in Lithuania compared to Estonia and Latvia. Nevertheless, by January 1997, the Baltic countries extended the agreement to cover these politically difficult areas. Indeed, the BFTA was the first free-trade area that had provided for completely liberalized trade in agricultural and food products prior to the formation of a customs union and the harmonization of domestic support and foreign trade policies (Kazlauskiene and Meyers, 1999).

The Europe Agreements, CEFTA, and BFTA laid the basis for a period of exceptional CEEC export growth (see Table 1). Between 1993 and 2001, BFTA total export receipts increased by almost 400 percent, while the CEFTA's receipts benefited from a marginally less impressive growth rate of 250 percent. Between 1993 and 2001, the BFTA achieved a three-fold increase in exports to the EU, while the CEFTA achieved a two-fold increase (see Table 2). Furthermore, both the CEFTA and BFTA countries managed to increase their market share within the EU. Over the same period, the BFTA's market share increased from 0.11 percent to 0.26 percent, while the CEFTA increased its market share from 2.13 percent to 4.08 percent (see Table 3 ). ${ }^{6}$

Intraregional trade expanded in both the CEFTA and BFTA. Between 1993 and 2001 intraregional trade within the CEFTA doubled, while market share ${ }^{7}$ fell slightly from 11 percent to just under 10 percent (see Tables 4 and 5). However, performance varied within the group. Both the Czech Republic and Slovakia experienced a significant drop in intraregional market share. However, this was due to a decline in bilateral trade, after Czechoslovakia was dissolved. Hungary, Poland, and Romania all increased their share of intraregional trade, while Bulgaria and Slovenia largely maintained their respective shares. Both intraregional trade and market share increased in the BFTA area. Between 1993 and 2001, intraregional export receipts increased four-fold, while intraregional market share increased from 8.4 percent to 9.6 percent (see Tables 6 and 7).

\footnotetext{
${ }^{6}$ The higher increase in the exports of the BFTA countries is more marked if we take into account the fact that the Baltic countries were less developed when the transition started compared to the Central European countries (Feldman and Sally, 2002).

${ }^{7}$ Intraregional market share is defined as the proportion of regional imports that originated from other members of the region. For example, in the case of the CEFTA, intraregional market share is the ratio of CEFTA exports to other CEFTA countries as a percent of total CEFTA imports.
} 
While the CEFTA and BFTA sustained and developed intraregional trade, they did not prevent the CEECs from becoming increasingly dependent on EU markets. In 1993, CEFTA exports to the EU were 56 percent of total exports; by 2001, that figure had reached 68 percent. In the BFTA, that trend was less marked. In 1993, 50 percent of BFTA exports went to the EU; by 2001, that figure had risen to 55 percent (see Table 8). Ultimately, the asymmetric liberalization embedded in the Europe Agreements provided to be too strong to prevent the CEECs' growing dependence on the EU.

\section{Trade Liberalization in Southeastern European Countries}

As far as SEEC trade policy reform was concerned, the 1990s were a lost decade. As the former Socialist Federal Republic of Yugoslavia (SFRY) dissolved, the successor countries introduced restrictive trade regimes, each with their own tariff schedules and border controls. Moreover, the various wars that plagued the region during the first half of the 1990s disrupted several important transportation links. Consequently, regional trade flows virtually ceased. As the 1990s progressed, the successor states of the SFRY did little to reverse the decline in regional trade. Authoritarian and nationalist governments dominated the two largest countries in the region-Croatia and Serbia - and they had little interest in reforming regional trade arrangements. Furthermore, both countries were isolated internationally, albeit by different degrees of intensity. Consequently, the region failed to negotiate preferential trade agreements with the EU. After the Dayton agreement, the political environment prevented any rehabilitation of old trading relationships.

Regional trade data reflects this lack of progress. Between 1996 and 2001, the SEECs only managed to increase their total export receipts by 18 percent (see Table 1). Of course, we should treat pre-1996 trade data for the SEECs with some caution. For extended periods of time, Serbia and Montenegro were placed under sanctions and the data cannot account for unrecorded sanctions-busting trade. Military conflict played the major role in depressing trade performance, but its significance should not be overstated. The periods when conflict had subsided - for example 1996-99 and 2000-01—were not marked by a recovery in trade. Intraregional export receipts and market share fell every year between 1997 and 2000 (see Table 9). Furthermore, the SEEs had little success penetrating the CEFTA and BFTA markets (see Tables 3 and 7). The SEECs only made progress in the EU markets, where export receipts increased by 31 percent during 1996-2001, albeit from a comparatively low level.

The aftermath of the 1999 Kosovo crisis marked the first serious attempt to rebuild regional trade relationships. In June 1999, the international community created the Stability Pact for Southeastern Europe. Both the SEEC governments and the international community were determined to make trade-liberalization one of the main pillars of the post-conflict recovery of the region. The pact established a "working table" on economic reconstruction, which was given responsibility for regional economic cooperation. The Stability Pact envisaged a two-stage process. During the first stage, the SEECs would eliminate administrative barriers to trade, put a standstill on any new measures to restrict trade, and coordinate a reduction in trade barriers towards each other. During the second 
stage, the SEECs would accede to the WTO and establish a free-trade area that covered both the region and the EU (Michalopoulos 2002).

In order to meet its commitments under the Stability Pact, the EU launched the Stabilization and Association Process. The EU are now negotiating Stability and Association Agreements (SAAs) with each of the SEECs which, like the earlier Europe Agreements, provide an institutional framework for closer political and economic integration. ${ }^{8}$ Like their earlier counterparts, the SAAs also provide for asymmetric trade-liberalization. Even before negotiating the SAAs, the EU revised its trade preferences with the SEECs and unilaterally offered more generous market access. The new arrangement, known as Autonomous Trade Preferences, allowed duty and quota-free access for the majority of SEEC exports. Nevertheless, quotas remain on a few sensitive areas such as agriculture, wine, and textiles. These agreements can potentially create a hub-and-spoke problem directly comparable to that created by the Europe Agreements.

\section{The Stability Pact led directly to the SEECs signing a Memorandum of Understanding} (MoU) ${ }^{9}$ on trade liberalization in June 2001. Instead of immediately starting work on creating a regional free-trade area, the SEECs decided to create a network of limited bilateral agreements. During the discussions on the MoU, the option of a single comprehensive free-trade agreement was proposed. Despite its compelling logic, the SEEC representatives were not persuaded. They believed that the political will to develop a unified agreement did not exist at the time and that a network of bilateral agreements was a less risky and potentially more productive option (see Wijkman 2003). The memorandum set a target date of December 2002 to finish this work. As of March 2003, out of a total of 21 potential agreements, ten are now fully operational (see Table 10). As for the remaining agreements, four are signed and will shortly become fully operational, and seven agreements are initialed and await ratification. Nevertheless, in the case of those agreements not yet fully operational, tariffs on many items have been already lowered or abolished as a precursor to the agreements becoming effective.

The bilateral approach is problematic. Potentially, each bilateral agreement could be different and therefore this approach could create rather tangled, spaghetti-like trading relationships. The coverage of tariff lines could vary widely and each agreement may have a different liberalization timetable. The MoU did try to partly address this issue. It laid down some general guidelines which each agreement should adhere to. Most importantly, the memorandum set two targets: tariff rates should be abolished for at least 90 percent of all tariff lines, and tariff liberalization should cover at least 90 percent of bilateral trade by value. By spring 2003, most bilateral free-trade agreements had come close to fulfilling these

\footnotetext{
${ }^{8}$ The EU objective to support peace and stability in the region is contained in the 1995 Barcelona Declaration and in the Common Strategy adopted by the European Council in 2000 and was further supported by a series of bilateral agreements with other developing countries in the Mediterranean (see McQueen, 2002).

${ }^{9}$ The Memorandum of Understanding (MoU) was signed by Albania, Bosnia and Herzegovina, Bulgaria, Croatia, Macedonia, Romania, and Serbia and Montenegro. Later, Moldova also signed the MoU.
} 
targets. Messerlin and Miroudot (2003) reported that eleven ageements have already met the 90 percent targets, while in seven cases bilateral trade flows have reached 85 percent. These early successes in meeting the targets must be interpreted with care. As Messerlin and Miroudot point out, these 90 percent targets are easy to achieve when intraregional trade flows are still very low and comprise of a comparatively small number of products. This problem is particularly pressing in the case of agriculture, which is still heavily protected. The 90 percent targets have not created sufficient incentives for liberalizing trade in agricultural goods. Agriculture is comprised of a very small number of tariff lines and, because of the intense protection, is not traded much within the SEECs. Therefore, countries can easily meet these liberatization targets without any significant reduction in effective protection for their respective agricultural sectors.

Despite this progress, a number of problems remain. The effort to harmonize the agreements has inevitably meant that some important issues have been ignored. In particular, "behind-the-border" issues such as public procurement and services have been excluded. In general, the more recently signed bilateral agreements have been broadly similar in terms of their provisions. However, some free-trade agreements existed prior to the memorandum and differ signficantly with the general framework outlined in the memorandum. Furthermore, each agreement contains its own specific list of protected items. The bilateral approach does not offer any mechanism for harmonizing and ultimately reducing the list of protected goods. This will eventually put a break on any further trade reform.

More importantly, it is still unclear how the SEECs will move from the current bilateral framework to a more comprehensive free-trade area with the $E U$, which was envisaged in the Stability Pact. Thus, while the MoU certainly accelerated regional trade liberalization, the project is now coming to an end. If liberalization is to proceed further, then a more ambitous multilateral approach will be required. Three options are available to the SEECs: 1) joining the CEFTA; 2) harmonizing and extending the coverage of the current bilateral agreements, possibility on the basis of a new MoU; or 3) creating a new regional free-trade agreement. But before considering these options in detail, it is useful to further assess the impact of the CEFTA and BFTA on regional trade flows, using an estimated gravity model. As we shall see, the empirical evidence supports the hypothesis that the asymmetric liberalization reorientates trade towards the EU but that regional trade agreements can, to some extent, limit that tendency.

\section{ECONOMETRIC RESUlts}

In an effort to assess the contribution of the CEFTA and BFTA to the strong export performance in the CEECs, we estimated a gravity model comprising of 37 countries for the period 1996-2000. These 37 countries - primarly OECD, Eastern European and CIS countries - were the main trading partners of the CEECs and SEECs and therefore capture virtually all the export markets for these two regions. The time period was chosen to exclude the conflicts that afflicted the former Yugoslavia. Despite its simplicity, the gravity model is widely used in empirical trade theory; it fits well to any theory of international trade from Hecksher Ohlin to new trade theories (for a discussion see Deardorff, 1995). 
Previous authors have examined trade performance in transition economies using gravity models. However, the emphasis has tended to be on the effectiveness of the Europe Agreements, rather than on the CEFTA and BFTA (for an example see, Enders and Wonnacott, 1996). Some authors have looked at the underlying motivations for the CEFTA and BFTA. For example, Paas (2002) found that, for the Baltic countries, cultural proximity with its neighbors played an important role in re-establishing regional trade relationships. Others have used gravity models to examine why SEEC trade performance has been so poor. For example, Christie (2002) used a gravity model to examine SEEC trade performance. He found that in many cases, intraregional trade was much lower than what his estimated gravity model predicted.

We estimated an equation with the following functional form: ${ }^{10}$

$$
\begin{aligned}
& E X P_{i j t}=\beta_{o}+\beta_{1}\left|G D P C A P_{i t}-G D P C A P_{j t}\right|+\beta_{2}\left(\frac{G D P_{i t}+G D P_{j t}}{2}\right)+\beta_{3} S I M_{i j t}+ \\
& \beta_{5} D I S T_{i j}+\beta_{6} \text { Dummies }+e_{i t}
\end{aligned}
$$

Where:

$\begin{array}{lll}\mathrm{EXP}_{\mathrm{ijt}} & = & \text { exports of country } \mathrm{i} \text { to country } \mathrm{j} \text { at time } \mathrm{t}, \\ \mathrm{GDPCAP}_{\mathrm{it}} & = & \text { real GDP per capita of country } \mathrm{i} \text { at time } \mathrm{t} \\ \mathrm{GDPCAP}_{\mathrm{jt}} & = & \text { real GDP per capita of country } \mathrm{j} \text { at time } \mathrm{t} \\ \mathrm{DIST}_{\mathrm{ij}} & = & \text { distance in kilometers between the capitals of country } \mathrm{i} \text { and } \mathrm{j} . \\ \mathrm{SIM}_{\mathrm{ijt}} & = & \text { a similarity index. }\end{array}$

Size, similarity, and proximity are the starting points for gravity models. The larger and closer two countries are, the more they trade. Therefore trade flows are primarily explained by differences in GDP per capita, the average of GDP of the two countries, distance, and factors proxying for similarity.

The GDP per capita term of each country is a proxy for the capital-labor ratio. By implication, the absolute difference in GDP per capita between two countries captures the difference in capital-labor ratios and therefore relative factor endowments. If this difference is large, then inter-industry trade predominates (for a more general discussion, see Hummels and Levinsohn 1995). Moreover, the closer two economies are to each other, the lower the transportation costs and the higher the bilateral trade. The distance variable is a proxy for transportation costs. It measures the distance in kilometers between the two capital cities.

\footnotetext{
${ }^{10}$ The bilateral export data is taken from the IMF Direction of Trade database. We have taken the exchange rate, price, and real GDP per capita data from the Penn World Tables release 6.1. Distance data is taken from Byers (1999).
} 
Our specification also allows for the Linder hypothesis, which suggests that countries with similar demand patterns are more likely to trade with each other (Linder, 1961). In particular, countries with similar manufacturing sectors will typically produce similar products. Therefore, each country produces goods that are demanded by consumers in other countries. The Linder hypothesis is often cited as an explanation for the prevalence of trade between OECD countries, much of which tends to be intra-industry trade. In order to capture the Linder hypothesis, we constructed a similarity index that controls for the relative size of partner countries in terms of output and hopefully captures the bilateral intra-industry trade (see Egger, 2000). The index is defined as:

$S I M_{i j t}=\left[1-\left(\frac{G D P_{i t}}{G D P_{i t}+G D P_{j t}}\right)^{2}-\left(\frac{G D P_{j t}}{G D P_{i t}+G D P_{j t}}\right)^{2}\right]$

This index is bound between 0 and 0.5 . The larger the index, the more similar are the countries in terms of output and the higher their intra-industry trade.

We captured the effects of the Europe Agreements and the regional trade agreementsthe CEFTA and BFTA-with dummy variables. These variables account for the deviations from normal trade patterns. As previously argued, the Europe Agreements provided for asymmetric liberalization, with the EU liberalizing more quickly than the CEECs. Furthermore, the agreements limited the extent of trade reform in a number of sensitive areas, such as agriculture and textiles, where the CEECs had a comparative advantage. Therefore, the EU agreements will have a different impact on the CEECs and the EU. To control for this, we used two separate dummies: one measuring the impact of the Europe Agreements on the CEECs and one measuring the impact of the EU agreements on EU exports. In our regression, we called the first effect Europe Agreements and the second effect EU preferential access to the CEECs.

To take account of other country specific factors, we used dummy variables for language, common borders, and EU membership. We expected that countries with higher linguistic ties to have higher bilateral trade (for an example see Choi, 2002). The border dummy captures the potential common cultural ties between two adjacent countries that could facilitate trade. We also included a dummy variable for EU membership. The EU is a highly integrated bloc so we expected a higher than normal amount of trade between EU members.

Finally, we controlled for the earlier CMEA trade agreements. Since the CMEA was a forced agreement, pre-1990 trade was inefficiently high, there was little competition, and the quality of the products was poor. At the start of transition, few CEEC customers were willing to buy products from their former CMEA neighbors, and they turned to western producers. Thus, intra-CEEC trade fell during the early 1990s. Therefore, it is important to establish whether this fall was due to the after-effects of the CMEA agreement or if it is simply a return to the normal trading patterns. If the former is true, then the CMEA dummy variable must have a negative sign; if the latter is true, then the variable will be insignificant. 
We estimated our model incorporating all the variables and dummies using OLS, a random effects-GLS estimator, and a fixed effects-within estimator. We attempted a first interpretation of the results. Based upon the relevant tests, we found that the fixed effect-within estimator appeared to be the correct specification. However, the fixed effect-within estimator cannot give an estimate of the coefficients of the time invariant dummy variables since they are wiped out in the estimation. To solve this problem, we used a two-step procedure proposed by Hsiao (1986). We took the estimated fixed effect of the within estimator and performed a cross-section regression of the latter on the dummy variables discussed above. Since the estimated fixed effect from the first step is unbiased, we can use it for the second step estimation procedure.

\section{As Mátyás (1997, 1998) argued, the proper econometric specification of a panel data} gravity model is a three-way error component. This is because there is a need to take account of exporting as well as the importing country's special features and the time specific effect. However, all the variables in the gravity equation are constructed as measures of country i relative to country $\mathrm{j}$. So it seems more natural to us to assume that the specific effect in the error term is also expressed as a measure of country $i$ to country $j .{ }^{11}$ In other words, each cross section in our panel represents a different bilateral flow. Given the above, it would seem appropriate to estimate a two-way error component model. The Breuch and Pagen test gave a value of 9324.9, so the joint hypothesis that the time specific and the cross section specific effects are zero is rejected. However, if we test the hypothesis that the time specific effect is zero, we get an LM test statistic equal to 1.29 and thus we are unable to reject the null. In contrast, the hypothesis that the cross-section effect is zero is rejected (the respective LM test gave a value of 9323.6). Therefore, the cross-section specific effect could not be rejected. So we end up with a one-way error component model where the GLS estimator is preferred to the pooled OLS estimator.

In order to choose among alternative specifications, we performed a Hausman specification test (see Baltagi, 1995). This statistic will help us choose between the within fixed-effects and the GLS random effects estimators. The respective $X^{2}$ test statistic is 134 and thus the null hypothesis that the GLS estimator was the correct specification is rejected. Consequently, we concluded that the fixed-effects estimator was the more appropriate specification. Moreover, our findings were broadly consistent with those of Egger (2000).

Table 11 presents our estimation results. Since the within-fixed-effects estimator appears to be the most appropriate specification, we will focus on the interpretation of these results. All the variables have the expected signs. The coefficient of the GDP per capita variable is positively signed but insignificant. Recall that this variable suggests the predominance of inter-industry trade. The similarity variable is positively signed and statistically significant at the 10 percent confidence interval, suggesting the validity of the Linder hypothesis and the predominance of intra-industry trade in our sample.

\footnotetext{
11 This is consistent also with the trade theoretic methodology where all variables affecting trade are expressed in relative terms.
} 
Even though the GLS and OLS estimations do not represent the correct specification, we can use these results to form a preliminary idea about whether or not the preferential trade agreements and the other time invariant factors appear to have mattered. All but one of the preferential trade agreements have a positive and statistically significant impact on bilateral exports. The exception is the Europe Agreements, which is, in the case of the GLS estimation, a positive but statistically insignificant variable. Furthermore, both the distance and ex-CMEA variables are negative and statistically significant. In the second step of our estimation, we regressed the estimated fixed-effect given by the within estimator on a constant and the time invariant variables (see Appendix 1 for technical details). Initially, we performed a simple cross-section GLS regression to correct for the heteroskedasticity inherited in this two-step estimator (see Polacheck and Kim, 1994).

Table 11 also provides the results from the second stage cross-section of the two-step within estimator. All the preferential trade agreement variables are both positive and statistically significant. We therefore concluded that all the agreements were trade created for their members. The BFTA agreement was more effective than the CEFTA agreement. This is consistent with the fact that the BFTA agreement allowed more liberalized trade between its member states. More surprisingly, the parameter estimate for the Europe Agreements is smaller than either the CEFTA or BFTA parameters. Therefore, the bulk of the increase in EU-CEEC trade was due to a return to normal trading patterns rather than to the specific trade advantages offered by the Europe Agreements. As for all the other time invariant factors, they had the expected signs. However, the language dummy was insignificant, while the ex-CMEA dummy was negative and significant at a 10 percent confidence interval.

The above results give an explicit indication about the workings of the Europe Agreements. First of all the difference between the Europe Agreements and the EU preferential access to the CEECs' dummies emphasizes the asymmetric nature of the Europe Agreements. Furthermore, the large coefficients on the CEFTA and BFTA agreements, compared to the EU agreements, show the extent of the hub-and-spoke problem. Even though the Europe Agreements increased trade between the hub (EU) and the spokes (the CEECs), there was still considerable room for increased trade between the spokes. In this respect the CEFTA and BFTA agreements were a necessary condition for welfare gains from the Europe Agreements.

In order to get a rough idea of any gradual adjustment after the introduction of a preferential trade agreement, we performed a rather non-technical but very informative experiment. We estimated a cross-section variant of equation 1 for each time point of our data set. Although we obtained estimates for all the coefficients for each time period, we focused our attention on the coefficients for the various trade agreements. With the exception of the variable capturing the effects of Europe Agreements, the coefficients are rather smooth and stable (see Figure 1). The Europe Agreements' variable has an initial negative value but becomes positive for the remainder of the sample.

We also performed a poolability test to ensure that each cross section did not have specific information that warranted separate empirical investigation. This test gave an F-statistic of 0.60 compared to an F-critical of 1.5 at the one percent level of significance. This indicated that all the coefficients, including the dummy variables, are equal across time 
and thus the panel data estimation is appropriate. Given the estimate of the Europe Agreements' variable is not constant over time, we examined whether the coefficient derived from the 1996 cross section was significantly different to that derived from the 2000 cross section. The $t$ statistic was -3.31 and therefore we rejected the null hypothesis of equality over time. Therefore, we concluded that there was some evidence for an increasingly positive effect of the Europe Agreements.

\section{Policy Conclusions}

The originators of the CEFTA and BFTA can be satisfied with the achievements of these arrangements. The empirical evidence confirms that both arrangements had a positive effect on intraregional trade. Furthermore, these agreements confirmed the CEECs' capacity to develop cooperative multilateral structures. As time went on, CEFTA membership was expanded and its coverage of goods was increased. While the BFTA did not enlarge, it did tackle some very difficult issues, such as agriculture and fisheries. The agreements had a more limited effect on reducing the hub-and-spoke problem. Despite the significant regional trade-liberalization embedded within the agreements, the EU remained the dominant trading partner for all the CEECs.

The success of the two agreements offers some important lessons for the SEECs. Somewhat belatedly, the SEECs have taken a more serious approach to regional trade liberalization. The region is now finishing work on creating a network of bilateral free-trade agreements. However, once the network is complete, it is not clear where liberalization efforts in the SEECs will go. Ultimately, further progress would require a more multilateral approach. Broadly speaking, the SEECs have three options: 1) a southward enlargement of the CEFTA; 2) a further harmonization of the network of bilateral free-trade agreements (FTAs); and 3) the creation of a new FTA for the SEECs.

Accession to the CEFTA is an attractive option for the more advanced SEECs. In 2004, five of the eight members of the CEFTA will accede to the EU. A further southward enlargement of the CEFTA would provide an opportunity to deepen the recent steps made by the SEECs toward regional trade integration. This could provide an opportunity to reconsider the future of the CEFTA and even revise the membership criteria. However, a southward enlargement would require a relaxation of CEFTA membership rules. In particular, the requirement of World Trade Organization (WTO) membership as a prerequisite for CEFTA membership would have to be amended. Bosnia and Herzegovina, the former Yugoslav Republic of Macedonia, and Serbia and Montenegro are not yet members of the WTO and have much to do before WTO accession becomes a realistic prospect. To some extent, this has already started, as indicated by Croatia's recent accession to the CEFTA. Furthermore, the former Yugoslav Republic of Macedonia has also recently expressed a desire to join.

If the remaining three CEFTA members choose not to relax the membership criteria, then the SEECs could further develop the existing bilateral approach. The current agreements could be revised to cover more difficult and controversial areas, such as agriculture, services, and public procurement. However, this is unlikely to be achieved simply through the existing Memorandum of Understanding (MoU). The SEECs could develop a second MoU. This memorandum could lay out further guidelines for harmonizing 
the existing agreements and tackling trade liberalization in sensitive areas. On the basis of a second memorandum, the existing bilateral agreements could be renegotiated and extended. However, such an approach is likely to be complex and cumbersome and probably would not yield significant results.

Creating a more general multilateral agreement would be a more practical approach. The current network of bilateral free-trade agreements has laid the foundations for moving toward a more comprehensive regional free-trade agreement. This approach would further tackle the hub-and-spoke problem inherent in the trade agreements of the SEECs with the EU. A new general agreement could also offer the opportunity to include more difficult issues such as agriculture, services, and public procurement.

Within the next ten years, there is a realistic possibility that at least some countries within Southeastern Europe could join the European Union. The Stability and Association process holds out the possibility of a Balkan enlargement. Therefore, the SEECs now face the same challenges that the CEECs faced in the early 1990s. Can the SEECs adopt a more cooperative and multilateral approach to economic policy management, and can the the SEECs develop regional trade as a bulwark against growing dependence on EU markets? Like their northern counterparts, the SEECs may find that making further progress toward regional trade cooperation will strengthen the case for, and accelerate, a southward enlargement of the European Union. 


\section{DesCription OF Two-SteP, FiXed-EFfect Estimation Method}

Assume we have $\mathrm{N}$ bilateral flows and $\mathrm{T}$ time periods. In a simple linear panel data model with two variables, one of which is constant over time, we have:

$$
y_{i t}=X_{i t}^{\prime} \beta+D_{i}^{\prime} \gamma+e_{i t}
$$

where $y_{i t}$ is the NT $x 1$ column vector of the dependent variable, $X^{\prime}{ }_{i t}$ is the NT $x 1$ matrix of the independent variable and $\mathrm{D}_{i}$, a time invariant variable, $\beta$ is a scalar to be estimated, and $\mathrm{e}_{i t}$ is the disturbances. To decide which is the correct estimator for (A1), we must first determine how $\mathrm{e}_{\mathrm{it}}$ is specified.

According to the Breusch-Pagan LM test in $\mathrm{e}_{\mathrm{it}}$, there exists a cross-section specific effect but no time specific effect. So the correct assumption for $\mathrm{e}_{i t}$ is that:

$$
e_{i t}=\mu_{i}+\varepsilon_{i t}
$$

where $\varepsilon_{\text {it }}$ is a zero mean, constant variance random error. The $\mu_{\mathrm{i}}$ represents the unobservable cross-section (bilateral) specific effect. Furthermore, the Hausman test indicates that $\mu_{\mathrm{i}}$ is a fixed parameter. Thus in order to estimate (A1) we can simply take the average over time of equation (A1) and subtract it from (A1). This is the so-called within group-fixed effect estimator (see Baltagi, 1995):

$$
y_{i t}-\bar{y}_{i}=\left(X_{i t}^{\prime}-\bar{X}_{i t}^{\prime}\right) \beta+\left(e_{i t}-\bar{e}_{t}\right)
$$

In turn, this reduces to:

$$
\left(y_{i t}-\bar{y}_{i}\right)=\left(X_{i t}^{\prime}-\bar{X}_{i}^{\prime}\right) \beta+\left(\varepsilon_{i t}-\bar{\varepsilon}_{i}\right)
$$

To estimate $\beta$ in equation A4 we can simply use OLS. Note that what we have done here is to estimate our model in terms of deviations from the group means. This is done in order to wipe out the fixed-effect $\mu_{\mathrm{i}}$. However, by differencing from the group average we also wipe out all cross-section specific data. With equation (A3), we cannot directly estimate the cross-section specific dummies in our model. To overcome this difficulty we estimate (A4) with OLS and then calculated the estimated $\mu_{\mathrm{i}}$ by:

$$
\hat{\mu}_{i}=\bar{y}_{i}-\bar{X}_{i}^{\prime} \hat{\beta}
$$


where the hat above variables denotes predicted values. What we get is an unbiased ${ }^{12}$ estimator of $\mu_{\mathrm{i}}$. Given that it is unbiased we can estimate an equation of the form:

$$
\mu_{i}=\gamma D_{i}+u_{i}
$$

where (A6) is a regression of the estimated time invariant variables over the fixed-effect as estimated from (A4). So we can indirectly estimate the coefficient $\gamma$ of the time invariant variables involved in equation (A1) with the within-group estimator.

${ }^{12}$ But inconsistent. However we can use the estimated $\mu_{\mathrm{i}}$ in a second step regression and obtain unbiased and consistent estimates. 
Table 1. Central and Eastern Europe: Total Exports, 1993-2001

\begin{tabular}{|c|c|c|c|c|c|c|c|c|c|}
\hline & 1993 & 1994 & 1995 & 1996 & 1997 & 1998 & 1999 & 2000 & 2001 \\
\hline & \multicolumn{9}{|c|}{ (millions of U.S. dollars) } \\
\hline CEFTA & 53,427 & 65,591 & 83,184 & 89,284 & 98,065 & 109,873 & 109,496 & 124,400 & 134,523 \\
\hline Czech Republic & 11,774 & 14,281 & 17,178 & 22,132 & 22,504 & 26,420 & 26,238 & 28,941 & 30,050 \\
\hline Hungary & 8,598 & 10,588 & 12,861 & 13,145 & 19,100 & 23,005 & 24,849 & 28,087 & 30,153 \\
\hline Poland & 14,143 & 17,240 & 22,895 & 24,440 & 25,751 & 28,228 & 27,407 & 31,644 & 36,050 \\
\hline Romania & 4,892 & 6,160 & 8,061 & 7,644 & 8,387 & 8,315 & 8,509 & 10,367 & 11,386 \\
\hline Bulgaria & 2,319 & 3,400 & 5,220 & 4,781 & 4,314 & 4,150 & 3,755 & 4,760 & 5,062 \\
\hline Slovenia & 6,241 & 7,232 & 8,389 & 8,312 & 8,372 & 9,034 & 8,505 & 8,728 & 9,189 \\
\hline Slovak Republic & 5,460 & 6,691 & 8,579 & 8,831 & 9,639 & 10,720 & 10,233 & 11,874 & 12,631 \\
\hline BFTA & 3,004 & 4,330 & 5,829 & 6,782 & 8,464 & 8,766 & 7,744 & $\mathbf{9 , 5 0 2}$ & 10,593 \\
\hline Estonia & 805 & 1,312 & 1,840 & 2,077 & 2,931 & 3,244 & 3,017 & 3,828 & 4,011 \\
\hline Latvia & 1,040 & 990 & 1,284 & 1,424 & 1,670 & 1,811 & 1,723 & 1,865 & 2,000 \\
\hline Lithuania & 1,159 & 2,029 & 2,706 & 3,281 & 3,862 & 3,711 & 3,004 & 3,808 & 4,581 \\
\hline SEE & 5,171 & 5,582 & 6,154 & 6,730 & 7,358 & 8,009 & 7,111 & 7,339 & 7,973 \\
\hline Croatia & 3,904 & 4,260 & 4,632 & 4,512 & 4,332 & 4,557 & 4,226 & 4,071 & 4,543 \\
\hline Bosnia \& Herzegovina & 85 & 36 & 52 & 181 & 381 & 511 & 599 & 669 & 742 \\
\hline Albania & 122 & 141 & 202 & 211 & 141 & 206 & 275 & 255 & 319 \\
\hline Serbia \& Montenegro & 4 & 57 & 66 & 678 & 1,268 & 1,424 & 818 & 1,025 & 1,154 \\
\hline \multirow[t]{2}{*}{ Macedonia, FYR } & 1,055 & 1,086 & 1,203 & 1,148 & 1,237 & 1,311 & 1,192 & 1,319 & 1,216 \\
\hline & \multicolumn{9}{|c|}{ (Index 1996=100) } \\
\hline CEFTA & 60 & 73 & 93 & 100 & 110 & 123 & 123 & 139 & 151 \\
\hline Czech Republic & 53 & 65 & 78 & 100 & 102 & 119 & 119 & 131 & 136 \\
\hline Hungary & 65 & 81 & 98 & 100 & 145 & 175 & 189 & 214 & 229 \\
\hline Poland & 58 & 71 & 94 & 100 & 105 & 116 & 112 & 129 & 148 \\
\hline Romania & 64 & 81 & 105 & 100 & 110 & 109 & 111 & 136 & 149 \\
\hline Bulgaria & 49 & 71 & 109 & 100 & 90 & 87 & 79 & 100 & 106 \\
\hline Slovenia & 75 & 87 & 101 & 100 & 101 & 109 & 102 & 105 & 111 \\
\hline Slovak Republic & 62 & 76 & 97 & 100 & 109 & 121 & 116 & 134 & 143 \\
\hline BFTA & 44 & 64 & 86 & 100 & 125 & 129 & 114 & 140 & 156 \\
\hline Estonia & 39 & 63 & 89 & 100 & 141 & 156 & 145 & 184 & 193 \\
\hline Latvia & 73 & 70 & 90 & 100 & 117 & 127 & 121 & 131 & 140 \\
\hline Lithuania & 35 & 62 & 82 & 100 & 118 & 113 & 92 & 116 & 140 \\
\hline SEE & 77 & 83 & 91 & 100 & 109 & 119 & 106 & 109 & 118 \\
\hline Croatia & 87 & 94 & 103 & 100 & 96 & 101 & 94 & 90 & 101 \\
\hline Bosnia \& Herzegovina & 47 & 20 & 28 & 100 & 210 & 282 & 331 & 369 & 409 \\
\hline Albania & 58 & 67 & 96 & 100 & 67 & 98 & 131 & 121 & 151 \\
\hline Serbia \& Montenegro & 1 & 8 & 10 & 100 & 187 & 210 & 121 & 151 & 170 \\
\hline Macedonia, FYR & 92 & 95 & 105 & 100 & 108 & 114 & 104 & 115 & 106 \\
\hline \multicolumn{10}{|l|}{ Memorandum items } \\
\hline \multicolumn{10}{|c|}{$\overline{\text { Cumulative export growth (1993-2001) }}$} \\
\hline CEFTA & 253 & & & & & & & & \\
\hline BFTA & 398 & & & & & & & & \\
\hline SEE & 92 & & & & & & & & \\
\hline
\end{tabular}

Source: IMF, Direction of Trade database.

Notes: CEFTA denotes the Central European Free Trade Area; BFTA denotes the Baltic Free Trade Area; and SEE denotes Southeastern European countries. 
Table 2. Central and Eastern Europe: Exports to European Union (EU), 1993-2001

\begin{tabular}{|c|c|c|c|c|c|c|c|c|c|}
\hline & 1993 & 1994 & 1995 & 1996 & 1997 & 1998 & 1999 & 2000 & 2001 \\
\hline & \multicolumn{9}{|c|}{ (millions of U.S. dollars) } \\
\hline CEFTA & 29,712 & 37,641 & 48,646 & 52,438 & 60,249 & 72,436 & $\mathbf{7 5 , 7 4 7}$ & 84,861 & 91,769 \\
\hline Czech Republic & 6,354 & 7,480 & 9,273 & 12,760 & 13,557 & 16,976 & 18,172 & 19,905 & 20,490 \\
\hline Hungary & 4,982 & 6,818 & 8,077 & 8,234 & 13,603 & 16,782 & 18,927 & 21,117 & 22,435 \\
\hline Poland & 9,794 & 11,929 & 16,039 & 16,248 & 16,533 & 19,285 & 19,338 & 22,154 & 24,995 \\
\hline Romania & 2,027 & 2,970 & 4,388 & 4,271 & 4,752 & 5,369 & 5,572 & 6,630 & 7,737 \\
\hline Bulgaria & 1,090 & 1,564 & 2,013 & 1,913 & 1,942 & 2,137 & 2,035 & 2,463 & 2,794 \\
\hline Slovenia & 3,847 & 4,539 & 5,648 & 5,369 & 5,321 & 5,917 & 5,625 & 5,577 & 5,750 \\
\hline Slovak Republic & 1,618 & 2,340 & 3,208 & 3,645 & 4,540 & 5,970 & 6,076 & 7,015 & 7,569 \\
\hline BFTA & 1,498 & 1,628 & 2,557 & 2,784 & 3,495 & 4,223 & 4,477 & 5,653 & 5,819 \\
\hline Estonia & 389 & 628 & 1,006 & 1,060 & 1,424 & 1,788 & 1,894 & 2,623 & 2,405 \\
\hline Latvia & 334 & 389 & 568 & 628 & 815 & 1,025 & 1,078 & 1,206 & 1,225 \\
\hline Lithuania & 776 & 610 & 984 & 1,096 & 1,256 & 1,409 & 1,505 & 1,824 & 2,189 \\
\hline SEE & 2,704 & 3,020 & 3,308 & 3,571 & 4,023 & 4,230 & 3,810 & 4,161 & 4,671 \\
\hline Croatia & 2,214 & 2,531 & 2,672 & 2,302 & 2,220 & 2,172 & 2,088 & 2,234 & 2,467 \\
\hline Bosnia \& Herzegovina & 34 & 14 & 29 & 80 & 168 & 253 & 367 & 447 & 498 \\
\hline Albania & 89 & 109 & 160 & 181 & 124 & 191 & 258 & 231 & 286 \\
\hline Serbia \& Montenegro & 3 & 5 & 38 & 516 & 1,055 & 1,036 & 564 & 686 & 894 \\
\hline \multirow[t]{2}{*}{ Macedonia, FYR } & 364 & 361 & 409 & 491 & 456 & 578 & 533 & 561 & 526 \\
\hline & \multicolumn{9}{|c|}{ (Index 1996=100) } \\
\hline CEFTA & 57 & 72 & 93 & 100 & 115 & 138 & 144 & 162 & 175 \\
\hline Czech Republic & 50 & 59 & 73 & 100 & 106 & 133 & 142 & 156 & 161 \\
\hline Hungary & 61 & 83 & 98 & 100 & 165 & 204 & 230 & 256 & 272 \\
\hline Poland & 60 & 73 & 99 & 100 & 102 & 119 & 119 & 136 & 154 \\
\hline Romania & 47 & 70 & 103 & 100 & 111 & 126 & 130 & 155 & 181 \\
\hline Bulgaria & 57 & 82 & 105 & 100 & 102 & 112 & 106 & 129 & 146 \\
\hline Slovenia & 72 & 85 & 105 & 100 & 99 & 110 & 105 & 104 & 107 \\
\hline Slovak Republic & 44 & 64 & 88 & 100 & 125 & 164 & 167 & 192 & 208 \\
\hline BFTA & 54 & 58 & 92 & 100 & 126 & 152 & 161 & 203 & 209 \\
\hline Estonia & 37 & 59 & 95 & 100 & 134 & 169 & 179 & 248 & 227 \\
\hline Latvia & 53 & 62 & 90 & 100 & 130 & 163 & 172 & 192 & 195 \\
\hline Lithuania & 71 & 56 & 90 & 100 & 115 & 129 & 137 & 166 & 200 \\
\hline SEE & 76 & 85 & 93 & 100 & 113 & 118 & 107 & 117 & 131 \\
\hline Croatia & 96 & 110 & 116 & 100 & 96 & 94 & 91 & 97 & 107 \\
\hline Bosnia \& Herzegovina & 42 & 18 & 36 & 100 & 208 & 314 & 456 & 556 & 619 \\
\hline Albania & 49 & 60 & 89 & 100 & 68 & 106 & 142 & 128 & 158 \\
\hline Serbia \& Montenegro & 1 & 1 & 7 & 100 & 204 & 201 & 109 & 133 & 173 \\
\hline Macedonia, FYR & 74 & 74 & 83 & 100 & 93 & 118 & 109 & 114 & 107 \\
\hline \multicolumn{10}{|c|}{ Memorandum items } \\
\hline \multicolumn{10}{|c|}{ Cumulative export growth (1993-2001) } \\
\hline CEFTA & 209 & & & & & & & & \\
\hline BFTA & 288 & & & & & & & & \\
\hline SEE & 73 & & & & & & & & \\
\hline
\end{tabular}

Source: IMF, Direction of Trade database.

Notes: CEFTA denotes the Central European Free Trade Area; BFTA denotes the Baltic Free Trade Area; and SEE denotes Southeastern European countries. 
Table 3. Central and Eastern Europe: Market Share of EU Imports, 1993-2001

\begin{tabular}{|c|c|c|c|c|c|c|c|c|c|}
\hline & 1993 & 1994 & 1995 & 1996 & 1997 & 1998 & 1999 & 2000 & 2001 \\
\hline & \multicolumn{9}{|c|}{ (Exports in percent of total EU imports) } \\
\hline CEFTA & 2.13 & 2.37 & 2.54 & 2.68 & 3.05 & 3.51 & 3.51 & 3.71 & 4.08 \\
\hline Czech Republic & 0.46 & 0.47 & 0.48 & 0.65 & 0.69 & 0.82 & 0.84 & 0.87 & 0.91 \\
\hline Hungary & 0.36 & 0.43 & 0.42 & 0.42 & 0.69 & 0.81 & 0.88 & 0.92 & 1.00 \\
\hline Poland & 0.70 & 0.75 & 0.84 & 0.83 & 0.84 & 0.93 & 0.90 & 0.97 & 1.11 \\
\hline Romania & 0.15 & 0.19 & 0.23 & 0.22 & 0.24 & 0.26 & 0.26 & 0.29 & 0.34 \\
\hline Bulgaria & 0.08 & 0.10 & 0.11 & 0.10 & 0.10 & 0.10 & 0.09 & 0.11 & 0.12 \\
\hline Slovenia & 0.28 & 0.29 & 0.30 & 0.27 & 0.27 & 0.29 & 0.26 & 0.24 & 0.26 \\
\hline Slovak Republic & 0.12 & 0.15 & 0.17 & 0.19 & 0.23 & 0.29 & 0.28 & 0.31 & 0.34 \\
\hline BFTA & 0.11 & 0.10 & 0.13 & 0.14 & 0.18 & 0.20 & 0.21 & 0.25 & 0.26 \\
\hline Estonia & 0.03 & 0.04 & 0.05 & 0.05 & 0.07 & 0.09 & 0.09 & 0.11 & 0.11 \\
\hline Latvia & 0.02 & 0.02 & 0.03 & 0.03 & 0.04 & 0.05 & 0.05 & 0.05 & 0.05 \\
\hline Lithuania & 0.06 & 0.04 & 0.05 & 0.06 & 0.06 & 0.07 & 0.07 & 0.08 & 0.10 \\
\hline SEE & 0.19 & 0.19 & 0.17 & 0.18 & 0.20 & 0.21 & 0.18 & 0.18 & 0.21 \\
\hline Croatia & 0.16 & 0.16 & 0.14 & 0.12 & 0.11 & 0.11 & 0.10 & 0.10 & 0.11 \\
\hline Bosnia \& Herzegovina & 0.00 & 0.00 & 0.00 & 0.00 & 0.01 & 0.01 & 0.02 & 0.02 & 0.02 \\
\hline Albania & 0.01 & 0.01 & 0.01 & 0.01 & 0.01 & 0.01 & 0.01 & 0.01 & 0.01 \\
\hline Serbia \& Montenegro & 0.00 & 0.00 & 0.00 & 0.03 & 0.05 & 0.05 & 0.03 & 0.03 & 0.04 \\
\hline Macedonia, FYR & 0.03 & 0.02 & 0.02 & 0.03 & 0.02 & 0.03 & 0.02 & 0.02 & 0.02 \\
\hline \multicolumn{10}{|l|}{ Memorandum item } \\
\hline Total imports of the EU (billions of U.S. dollars) & 1,395 & 1,588 & 1,914 & 1,956 & 1,974 & 2,063 & 2,158 & 2,287 & 2,247 \\
\hline
\end{tabular}

Source: IMF, Direction of Trade database.

Notes: CEFTA denotes the Central European Free Trade Area; BFTA denotes the Baltic Free Trade Area; SEE denotes Southeastern European countries; and EU denotes the European Union. 
Table 4. Central and Eastern Europe: Exports to Central European Free Trade Area (CEFTA) Markets, 1993-2001

\begin{tabular}{|c|c|c|c|c|c|c|c|c|c|}
\hline & 1993 & 1994 & 1995 & 1996 & 1997 & 1998 & 1999 & 2000 & 2001 \\
\hline & \multicolumn{9}{|c|}{ (millions of U.S. dollars) } \\
\hline CEFTA 1/ & 7,775 & 9,283 & 12,118 & 12,874 & 13,169 & 14,234 & 13,226 & 15,108 & 16,488 \\
\hline Czech Republic & 3,299 & 3,553 & 4,405 & 5,085 & 4,975 & 5,301 & 4,611 & 4,838 & 5,032 \\
\hline Hungary & 371 & 989 & 1,409 & 1,459 & 1,748 & 2,086 & 1,947 & 2,289 & 2,719 \\
\hline Poland & 598 & 735 & 1,381 & 1,602 & 1,802 & 2,091 & 2,237 & 2,662 & 3,149 \\
\hline Romania & 267 & 379 & 338 & 341 & 403 & 447 & 597 & 848 & 808 \\
\hline Bulgaria & 127 & 149 & 193 & 170 & 144 & 212 & 173 & 191 & 247 \\
\hline Slovenia & 316 & 335 & 437 & 482 & 517 & 607 & 616 & 691 & 739 \\
\hline Slovak Republic & 2,797 & 3,143 & 3,956 & 3,734 & 3,581 & 3,489 & 3,044 & 3,588 & 3,794 \\
\hline BFTA 2/ & 153 & 193 & 223 & 209 & 196 & 231 & 261 & 383 & 472 \\
\hline Estonia & 20 & 21 & 31 & 31 & 32 & 31 & 35 & 59 & 70 \\
\hline Latvia & 41 & 26 & 47 & 35 & 35 & 48 & 45 & 59 & 68 \\
\hline Lithuania & 92 & 146 & 146 & 143 & 129 & 152 & 181 & 265 & 334 \\
\hline SEE 2/ & 1,017 & 1,078 & 1,180 & 1,059 & 1,000 & 982 & 841 & 896 & 857 \\
\hline Croatia & 803 & 730 & 795 & 796 & 718 & 561 & 574 & 568 & 563 \\
\hline Bosnia \& Herzegovina & 15 & 5 & 8 & 18 & 38 & 59 & 62 & 73 & 77 \\
\hline Albania & 4 & 3 & 4 & 4 & 3 & 3 & 2 & 2 & 2 \\
\hline Serbia \& Montenegro & 0 & 0 & 0 & 105 & 128 & 255 & 129 & 191 & 160 \\
\hline \multirow[t]{2}{*}{ Macedonia, FYR } & 196 & 341 & 372 & 137 & 113 & 104 & 73 & 62 & 54 \\
\hline & \multicolumn{9}{|c|}{ (Index 1996=100) } \\
\hline CEFTA & 60.4 & 72.1 & 94.1 & 100.0 & 102.3 & 110.6 & 102.7 & 117.3 & 128.1 \\
\hline Czech Republic & 64.9 & 69.9 & 86.6 & 100.0 & 97.8 & 104.2 & 90.7 & 95.1 & 99.0 \\
\hline Hungary & 25.4 & 67.8 & 96.6 & 100.0 & 119.8 & 143.0 & 133.5 & 156.9 & 186.4 \\
\hline Poland & 37.3 & 45.9 & 86.2 & 100.0 & 112.4 & 130.5 & 139.6 & 166.1 & 196.5 \\
\hline Romania & 78.4 & 111.2 & 99.0 & 100.0 & 118.2 & 131.1 & 175.2 & 248.8 & 236.8 \\
\hline Bulgaria & 74.8 & 87.5 & 113.3 & 100.0 & 84.5 & 124.6 & 101.7 & 112.0 & 145.1 \\
\hline Slovenia & 65.4 & 69.4 & 90.6 & 100.0 & 107.1 & 125.9 & 127.7 & 143.3 & 153.3 \\
\hline Slovak Republic & 74.9 & 84.2 & 105.9 & 100.0 & 95.9 & 93.4 & 81.5 & 96.1 & 101.6 \\
\hline BFTA & 73.2 & 92.2 & 106.8 & 100.0 & 94.0 & 110.4 & 125.0 & 183.1 & 226.1 \\
\hline Estonia & 63.8 & 67.4 & 98.1 & 100.0 & 103.5 & 99.5 & 112.4 & 189.6 & 224.0 \\
\hline Latvia & 117.3 & 74.5 & 133.3 & 100.0 & 99.9 & 135.3 & 129.2 & 167.0 & 194.8 \\
\hline Lithuania & 64.3 & 102.0 & 102.1 & 100.0 & 90.5 & 106.6 & 126.7 & 185.7 & 234.2 \\
\hline SEE & 96.1 & 101.8 & 111.5 & 100.0 & 94.4 & 92.7 & 79.4 & 84.6 & 80.9 \\
\hline Croatia & 100.9 & 91.7 & 100.0 & 100.0 & 90.3 & 70.5 & 72.2 & 71.4 & 70.7 \\
\hline Bosnia \& Herzegovina & 82.0 & 27.3 & 44.5 & 100.0 & 213.6 & 331.4 & 353.1 & 415.6 & 437.3 \\
\hline Albania & 102.3 & 73.1 & 119.2 & 100.0 & 72.6 & 94.2 & 60.8 & 45.4 & 54.9 \\
\hline Serbia \& Montenegro & 0.0 & 0.0 & 0.5 & 100.0 & 121.8 & 242.7 & 122.5 & 182.0 & 152.7 \\
\hline Macedonia, FYR & 143.6 & 249.3 & 272.1 & 100.0 & 82.6 & 76.1 & 53.5 & 45.2 & 39.7 \\
\hline \multicolumn{10}{|c|}{ Memorandum items } \\
\hline \multicolumn{10}{|c|}{$\overline{\text { Cumulative export growth (1993-2001) }}$} \\
\hline CEFTA & 112 & & & & & & & & \\
\hline BFTA & 209 & & & & & & & & \\
\hline SEEC & -16 & & & & & & & & \\
\hline
\end{tabular}

Source: IMF, Direction of Trade database.

Notes: CEFTA denotes the Central European Free Trade Area; BFTA denotes the Baltic Free Trade Area; and SEE denotes Southeastern European countries. 1/ Exports of CEFTA member countries to other CEFTA members

2/ Exports of BFTA and SEE to CEFTA members 
Table 5. Central and Eastern Europe: Market Share of CEFTA Countries’ Imports, 1993-2001

\begin{tabular}{|c|c|c|c|c|c|c|c|c|c|}
\hline & 1993 & 1994 & 1995 & 1996 & 1997 & 1998 & 1999 & 2000 & 2001 \\
\hline & \multicolumn{9}{|c|}{ (exports as a percent of total CEFTA imports) } \\
\hline Intraregional trade & 11.1 & 11.7 & 11.8 & 10.7 & 10.1 & 9.8 & 9.2 & 9.5 & 9.7 \\
\hline Czech Republic & 4.7 & 4.5 & 4.3 & 4.2 & 3.8 & 3.6 & 3.2 & 3.0 & 2.9 \\
\hline Hungary & 0.5 & 1.2 & 1.4 & 1.2 & 1.3 & 1.4 & 1.4 & 1.4 & 1.6 \\
\hline Poland & 0.9 & 0.9 & 1.3 & 1.3 & 1.4 & 1.4 & 1.6 & 1.7 & 1.8 \\
\hline Romania & 0.4 & 0.5 & 0.3 & 0.3 & 0.3 & 0.3 & 0.4 & 0.5 & 0.5 \\
\hline Bulgaria & 0.2 & 0.2 & 0.2 & 0.1 & 0.1 & 0.1 & 0.1 & 0.1 & 0.1 \\
\hline Slovenia & 0.5 & 0.4 & 0.4 & 0.4 & 0.4 & 0.4 & 0.4 & 0.4 & 0.4 \\
\hline Slovak Republic & 4.0 & 4.0 & 3.9 & 3.1 & 2.7 & 2.4 & 2.1 & 2.2 & 2.2 \\
\hline BFTA & 0.2 & 0.2 & 0.2 & 0.2 & 0.2 & 0.2 & 0.2 & 0.2 & 0.3 \\
\hline Estonia & 0.0 & 0.0 & 0.0 & 0.0 & 0.0 & 0.0 & 0.0 & 0.0 & 0.0 \\
\hline Latvia & 0.1 & 0.0 & 0.0 & 0.0 & 0.0 & 0.0 & 0.0 & 0.0 & 0.0 \\
\hline Lithuania & 0.1 & 0.2 & 0.1 & 0.1 & 0.1 & 0.1 & 0.1 & 0.2 & 0.2 \\
\hline SEE & 1.5 & 1.4 & 1.1 & 0.9 & 0.8 & 0.7 & 0.6 & 0.6 & 0.5 \\
\hline Croatia & 1.1 & 0.9 & 0.8 & 0.7 & 0.6 & 0.4 & 0.4 & 0.4 & 0.3 \\
\hline Bosnia \& Herzegovina & 0.0 & 0.0 & 0.0 & 0.0 & 0.0 & 0.0 & 0.0 & 0.0 & 0.0 \\
\hline Albania & 0.0 & 0.0 & 0.0 & 0.0 & 0.0 & 0.0 & 0.0 & 0.0 & 0.0 \\
\hline Serbia \& Montenegro & 0.0 & 0.0 & 0.0 & 0.1 & 0.1 & 0.2 & 0.1 & 0.1 & 0.1 \\
\hline Macedonia, FYR & 0.3 & 0.4 & 0.4 & 0.1 & 0.1 & 0.1 & 0.1 & 0.0 & 0.0 \\
\hline \multicolumn{10}{|l|}{ Memorandum item } \\
\hline Total imports of CEFTA (millions of U.S. dollars) & 69,863 & 79,474 & 102,656 & 120,345 & 130,499 & 145,932 & 143,116 & 159,754 & 170,849 \\
\hline
\end{tabular}

Source: IMF, Direction of Trade database.

Notes: CEFTA denotes the Central European Free Trade Area; BFTA denotes the Baltic Free Trade Area; and SEE denotes Southeastern European countries. 
Table 6. Central and Eastern Europe: Exports to Baltic Free Trade Area (BFTA) Markets, 1993-2001

\begin{tabular}{|c|c|c|c|c|c|c|c|c|c|}
\hline & 1993 & 1994 & 1995 & 1996 & 1997 & 1998 & 1999 & 2000 & 2001 \\
\hline & \multicolumn{9}{|c|}{ (millions of U.S. dollars) } \\
\hline CEFTA $2 /$ & 103 & 324 & 473 & 680 & 847 & 1,065 & 1,050 & 1,212 & 1,516 \\
\hline Czech Republic & 10 & 55 & 79 & 125 & 148 & 201 & 153 & 174 & 194 \\
\hline Hungary & 0 & 44 & 66 & 106 & 99 & 96 & 92 & 91 & 119 \\
\hline Poland & 74 & 173 & 267 & 368 & 508 & 681 & 728 & 859 & 1,089 \\
\hline Romania & 2 & 7 & 2 & 3 & 4 & 3 & 2 & 2 & 5 \\
\hline Bulgaria & 2 & 13 & 16 & 23 & 17 & 21 & 18 & 16 & 17 \\
\hline Slovenia & 4 & 9 & 12 & 17 & 19 & 23 & 28 & 28 & 39 \\
\hline Slovak Republic & 10 & 24 & 31 & 39 & 50 & 39 & 29 & 42 & 52 \\
\hline BFTA 1/ & 279 & 482 & 577 & 837 & 1,056 & 1,182 & 1,042 & 1,293 & 1,447 \\
\hline Estonia & 99 & 179 & 213 & 290 & 431 & 457 & 378 & 395 & 443 \\
\hline Latvia & 62 & 80 & 113 & 160 & 195 & 217 & 210 & 240 & 277 \\
\hline Lithuania & 118 & 223 & 252 & 386 & 430 & 508 & 454 & 658 & 728 \\
\hline SEE 2/ & $\mathbf{0}$ & 1 & 1 & 1 & 2 & 2 & 2 & 3 & 9 \\
\hline Croatia & 0 & 1 & 1 & 1 & 2 & 2 & 2 & 3 & 8 \\
\hline Bosnia \& Herzegovina & 0 & 0 & 0 & 0 & 0 & 0 & 0 & 0 & 1 \\
\hline Albania & 0 & 0 & 0 & 0 & 0 & 0 & 0 & 0 & 0 \\
\hline Serbia \& Montenegro & 0 & 0 & 0 & 0 & 0 & 0 & 0 & 0 & 0 \\
\hline \multirow[t]{2}{*}{ Macedonia, FYR } & 0 & 0 & 0 & 0 & 0 & 0 & 0 & 0 & 0 \\
\hline & \multicolumn{9}{|c|}{ (Index 1996=100) } \\
\hline CEFTA & 15.1 & 47.7 & 69.6 & 100.0 & 124.5 & 156.6 & 154.5 & 178.2 & 222.9 \\
\hline Czech Republic & 8.0 & 43.5 & 63.3 & 100.0 & 118.0 & 160.7 & 122.1 & 138.4 & 155.1 \\
\hline Hungary & 0.0 & 41.8 & 62.5 & 100.0 & 93.7 & 90.9 & 87.5 & 86.2 & 112.6 \\
\hline Poland & 20.1 & 47.0 & 72.4 & 100.0 & 138.0 & 185.0 & 197.5 & 233.1 & 295.7 \\
\hline Romania & 96.0 & 288.0 & 72.0 & 100.0 & 168.0 & 134.8 & 85.6 & 94.0 & 212.0 \\
\hline Bulgaria & 10.2 & 58.5 & 69.0 & 100.0 & 75.9 & 91.3 & 79.7 & 71.7 & 74.0 \\
\hline Slovenia & 24.8 & 51.7 & 74.3 & 100.0 & 116.5 & 137.3 & 168.5 & 169.6 & 233.3 \\
\hline Slovak Republic & 25.0 & 60.6 & 80.4 & 100.0 & 129.7 & 101.3 & 74.6 & 107.3 & 135.0 \\
\hline BFTA & 33.3 & 57.6 & 69.0 & 100.0 & 126.2 & 141.3 & 124.6 & 154.6 & 173.0 \\
\hline Estonia & 34.1 & 61.7 & 73.4 & 100.0 & 148.5 & 157.6 & 130.1 & 136.1 & 152.5 \\
\hline Latvia & 38.8 & 50.3 & 70.4 & 100.0 & 121.9 & 135.3 & 131.3 & 150.1 & 173.0 \\
\hline Lithuania & 30.5 & 57.7 & 65.1 & 100.0 & 111.3 & 131.5 & 117.7 & 170.3 & 188.5 \\
\hline SEE & 7.6 & 102.8 & 99.8 & 100.0 & 152.0 & 158.8 & 193.9 & 302.4 & 822.3 \\
\hline Croatia & 0.0 & 114.8 & 109.4 & 100.0 & 161.6 & 156.6 & 190.9 & 277.8 & 781.8 \\
\hline Bosnia \& Herzegovina & $\ldots$ & $\ldots$ & $\ldots$ & $\ldots$ & $\ldots$ & $\ldots$ & $\ldots$ & $\ldots$ & $\ldots$ \\
\hline Albania & $\ldots$ & $\ldots$ & $\ldots$ & $\ldots$ & $\ldots$ & $\ldots$ & $\ldots$ & $\ldots$ & $\ldots$ \\
\hline Serbia \& Montenegro & $\ldots$ & $\ldots$ & $\ldots$ & $\ldots$ & $\ldots$ & $\ldots$ & $\ldots$ & $\ldots$ & $\ldots$ \\
\hline Macedonia, FYR & 0.0 & 0.0 & 17.9 & 100.0 & 49.7 & 159.9 & 112.5 & 367.7 & 324.0 \\
\hline \multicolumn{10}{|c|}{ Memorandum items } \\
\hline \multicolumn{10}{|c|}{ Cumulative export growth (1993-2001) } \\
\hline CEFTA & 1,377 & & & & & & & & \\
\hline BFTA & 419 & & & & & & & & \\
\hline SEEC & 10,748 & & & & & & & & \\
\hline
\end{tabular}

Source: IMF, Direction of Trade database.

Notes: CEFTA denotes the Central European Free Trade Area; BFTA denotes the Baltic Free Trade Area; and SEEC denotes Southeastern European Countries. 1/ Exports of BFTA member countries to other BFTA members

2/ Exports of CEFTA and SEE to BFTA members 
Table 7. Central and Eastern Europe: Market Share of BFTA Countries’ Imports, 1993-2001

\begin{tabular}{|c|c|c|c|c|c|c|c|c|c|}
\hline & 1993 & 1994 & 1995 & 1996 & 1997 & 1998 & 1999 & 2000 & 2001 \\
\hline & \multicolumn{9}{|c|}{ (exports as a percent of total BFTA imports) } \\
\hline CEFTA & 3.1 & 6.0 & 5.9 & 6.9 & 6.6 & 7.7 & 8.8 & 8.9 & 10.1 \\
\hline Czech Republic & 0.3 & 1.0 & 1.0 & 1.3 & 1.2 & 1.5 & 1.3 & 1.3 & 1.3 \\
\hline Hungary & 0.0 & 0.8 & 0.8 & 1.1 & 0.8 & 0.7 & 0.8 & 0.7 & 0.8 \\
\hline Poland & 2.2 & 3.2 & 3.3 & 3.7 & 4.0 & 4.9 & 6.1 & 6.3 & 7.2 \\
\hline Romania & 0.1 & 0.1 & 0.0 & 0.0 & 0.0 & 0.0 & 0.0 & 0.0 & 0.0 \\
\hline Bulgaria & 0.1 & 0.2 & 0.2 & 0.2 & 0.1 & 0.2 & 0.2 & 0.1 & 0.1 \\
\hline Slovenia & 0.1 & 0.2 & 0.2 & 0.2 & 0.2 & 0.2 & 0.2 & 0.2 & 0.3 \\
\hline Slovak Republic & 0.3 & 0.4 & 0.4 & 0.4 & 0.4 & 0.3 & 0.2 & 0.3 & 0.3 \\
\hline Intraregional trade & 8.4 & 9.0 & 7.2 & 8.4 & 8.2 & 8.6 & 8.8 & 9.5 & 9.6 \\
\hline Estonia & 3.0 & 3.3 & 2.7 & 2.9 & 3.4 & 3.3 & 3.2 & 2.9 & 2.9 \\
\hline Latvia & 1.9 & 1.5 & 1.4 & 1.6 & 1.5 & 1.6 & 1.8 & 1.8 & 1.8 \\
\hline Lithuania & 3.5 & 4.1 & 3.1 & 3.9 & 3.4 & 3.7 & 3.8 & 4.8 & 4.8 \\
\hline SEE & 0.0 & 0.0 & 0.0 & 0.0 & 0.0 & 0.0 & 0.0 & 0.0 & 0.1 \\
\hline Croatia & 0.0 & 0.0 & 0.0 & 0.0 & 0.0 & 0.0 & 0.0 & 0.0 & 0.1 \\
\hline Bosnia \& Herzegovina & 0.0 & 0.0 & 0.0 & 0.0 & 0.0 & 0.0 & 0.0 & 0.0 & 0.0 \\
\hline Albania & 0.0 & 0.0 & 0.0 & 0.0 & 0.0 & 0.0 & 0.0 & 0.0 & 0.0 \\
\hline Serbia \& Montenegro & 0.0 & 0.0 & 0.0 & 0.0 & 0.0 & 0.0 & 0.0 & 0.0 & 0.0 \\
\hline Macedonia, FYR & 0.0 & 0.0 & 0.0 & 0.0 & 0.0 & 0.0 & 0.0 & 0.0 & 0.0 \\
\hline \multicolumn{10}{|l|}{ Memorandum item } \\
\hline Total imports of BFTA (millions of U.S. dollars) & 3,339 & 5,383 & 8,005 & 9,925 & 12,801 & 13,773 & 11,891 & 13,657 & 15,043 \\
\hline
\end{tabular}

Source: IMF, Direction of Trade database.

Notes: CEFTA denotes the Central European Free Trade Area; BFTA denotes the Baltic Free Trade Area; and SEE denotes Southeastern European countries. 
Table 8. Central and Eastern Europe: Exports to European Union (EU), 1993-2001

\begin{tabular}{|c|c|c|c|c|c|c|c|c|c|}
\hline & 1993 & 1994 & 1995 & 1996 & 1997 & 1998 & 1999 & 2000 & 2001 \\
\hline & \multicolumn{9}{|c|}{ (percent of total exports) } \\
\hline CEFTA & 56 & 57 & 58 & 59 & 61 & 66 & 69 & 68 & 68 \\
\hline Czech Republic & 54 & 52 & 54 & 58 & 60 & 64 & 69 & 69 & 68 \\
\hline Hungary & 58 & 64 & 63 & 63 & 71 & 73 & 76 & 75 & 74 \\
\hline Poland & 69 & 69 & 70 & 66 & 64 & 68 & 71 & 70 & 69 \\
\hline Romania & 41 & 48 & 54 & 56 & 57 & 65 & 65 & 64 & 68 \\
\hline Bulgaria & 47 & 46 & 39 & 40 & 45 & 51 & 54 & 52 & 55 \\
\hline Slovenia & 62 & 63 & 67 & 65 & 64 & 65 & 66 & 64 & 63 \\
\hline Slovak Republic & 30 & 35 & 37 & 41 & 47 & 56 & 59 & 59 & 60 \\
\hline BFTA & $\mathbf{5 0}$ & 38 & 44 & 41 & 41 & 48 & 58 & 59 & 55 \\
\hline Estonia & 48 & 48 & 55 & 51 & 49 & 55 & 63 & 69 & 60 \\
\hline Latvia & 32 & 39 & 44 & 44 & 49 & 57 & 63 & 65 & 61 \\
\hline Lithuania & 67 & 30 & 36 & 33 & 33 & 38 & 50 & 48 & 48 \\
\hline SEE & 52 & 54 & 54 & 53 & 55 & 53 & 54 & 57 & 59 \\
\hline Croatia & 57 & 59 & 58 & 51 & 51 & 48 & 49 & 55 & 54 \\
\hline Bosnia \& Herzegovina & 40 & 40 & 56 & 44 & 44 & 49 & 61 & 67 & 67 \\
\hline Albania & 73 & 77 & 79 & 86 & 87 & 93 & 94 & 91 & 90 \\
\hline Serbia \& Montenegro & 81 & 9 & 58 & 76 & 83 & 73 & 69 & 67 & 77 \\
\hline Macedonia, FYR & 35 & 33 & 34 & 43 & 37 & 44 & 45 & 43 & 43 \\
\hline
\end{tabular}

Source: IMF, Direction of Trade database.

Notes: CEFTA denotes the Central European Free Trade Area; BFTA denotes the Baltic Free Trade Area; and SEE denotes Southeastern European countries. 
Table 9. Central and Eastern Europe: Exports to Southeastern European (SEE) markets, 1993-2001

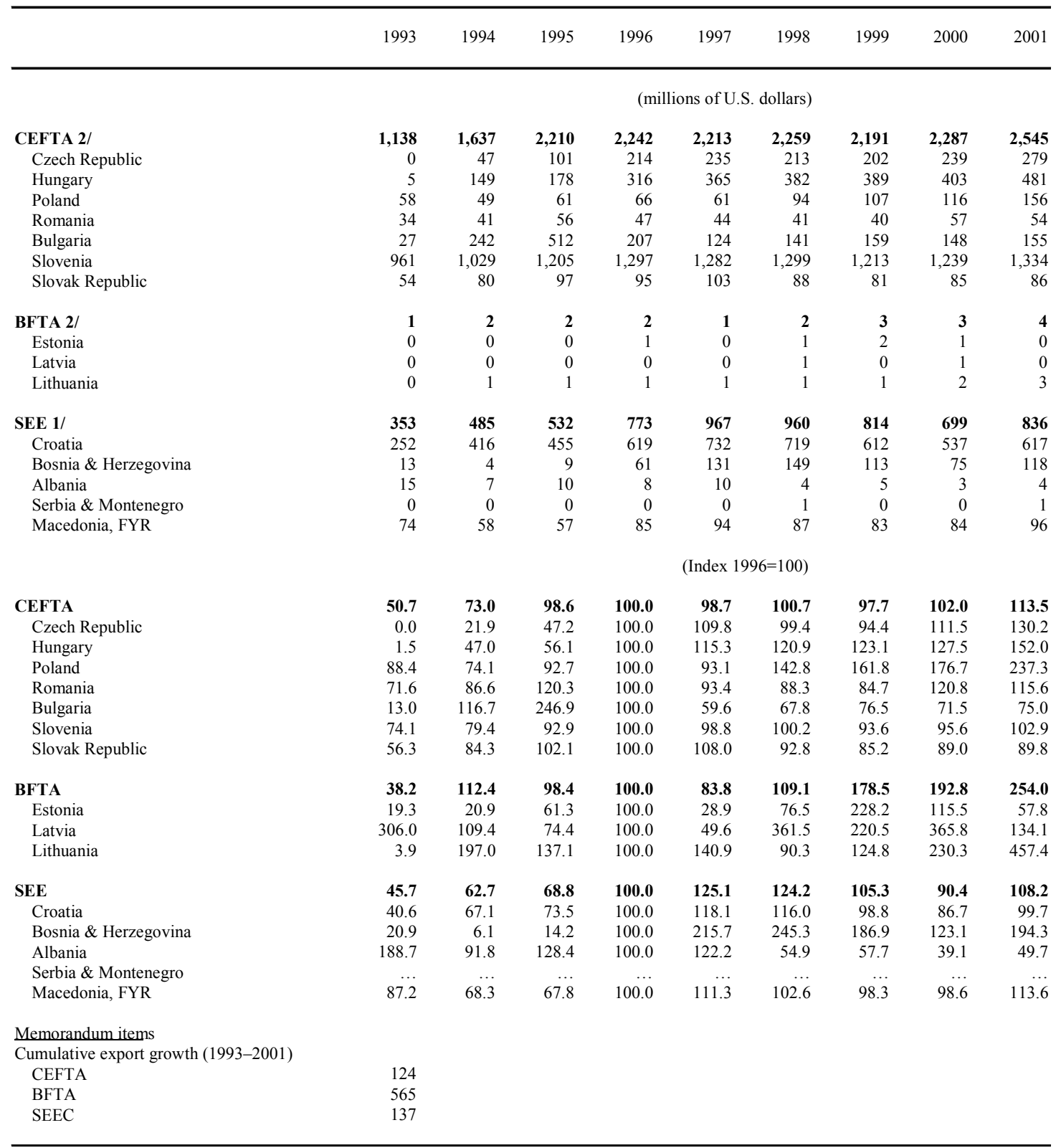

Source: IMF, Direction of Trade database.

Notes: CEFTA denotes the Central European Free Trade Area; BFTA denotes the Baltic Free Trade Area; and SEE denotes Southeastern European countries. 1/ Exports of SEE countries to other SEE countries

2/ Exports of CEFTA and BFTA to SEE members 


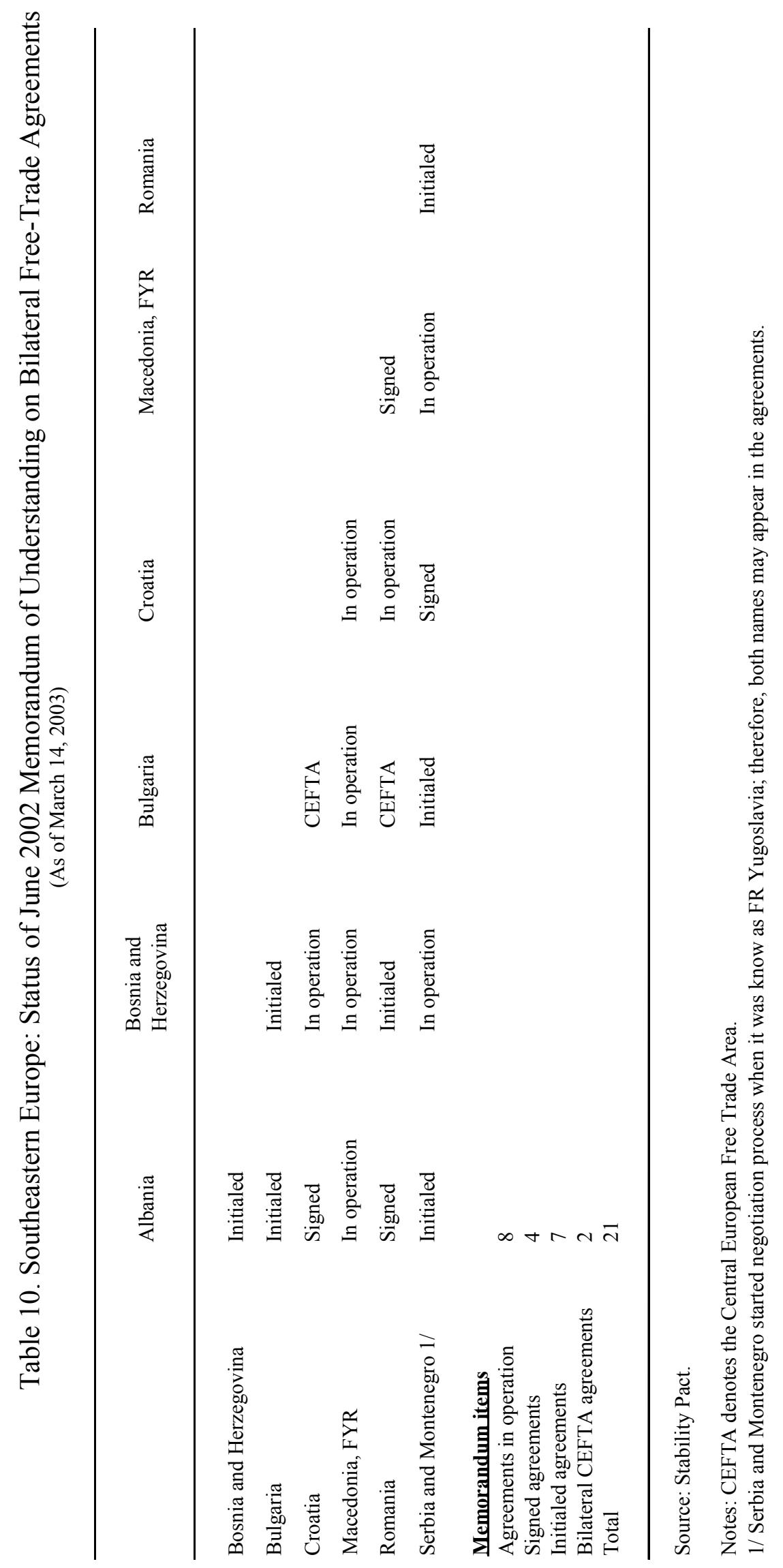


Table 11. Model Estimation

\begin{tabular}{|c|c|c|c|c|}
\hline & Fixed Effects & Random Effects & OLS & $\begin{array}{l}\text { Second-Stage } \\
\text { Cross Section }\end{array}$ \\
\hline Constant & $\begin{array}{r}-30,42 * * * \\
(-12.38)\end{array}$ & $\begin{array}{c}-32,1 * * * \\
(-36.68)\end{array}$ & $\begin{array}{r}-30,38 * * * \\
(-63.51)\end{array}$ & $\begin{array}{l}0.541 \\
(4.69)\end{array}$ \\
\hline Difference in GDP per capita & $\begin{array}{r}0.0523 \\
(0.44)\end{array}$ & $\begin{array}{r}-0,867 * * * \\
(12.95)\end{array}$ & $\begin{array}{r}-1.269 * * * \\
(-30.33)\end{array}$ & $\begin{array}{l}\cdots \\
\cdots\end{array}$ \\
\hline Average GDP & $\begin{array}{r}1,797 * * * \\
(14.44)\end{array}$ & $\begin{array}{l}1,9 * * * \\
(43.45)\end{array}$ & $\begin{array}{r}1.833 * * * \\
(78.16)\end{array}$ & $\begin{array}{l}\cdots \\
\cdots\end{array}$ \\
\hline Similarity & $\begin{array}{l}1,56^{*} \\
(1.73)\end{array}$ & $\begin{array}{r}4,87 * * * \\
(17.79)\end{array}$ & $\begin{array}{r}4.801 * * * \\
(37.12)\end{array}$ & $\begin{array}{l}\cdots \\
\cdots\end{array}$ \\
\hline Distance & $\begin{array}{l}\cdots \\
\cdots\end{array}$ & $\begin{array}{r}-0,0006 * * * \\
(-15.52)\end{array}$ & $\begin{array}{r}-0.0006 * * * \\
(-28.36)\end{array}$ & $\begin{array}{r}-0.0008 * * * \\
(-15.70)\end{array}$ \\
\hline Language & $\begin{array}{l}\cdots \\
\cdots\end{array}$ & $\begin{array}{r}0,497 * * \\
(2.05)\end{array}$ & $\begin{array}{r}0.549 * * * \\
(5.92)\end{array}$ & $\begin{array}{l}0.059 \\
(0.35)\end{array}$ \\
\hline BFTA & $\begin{array}{l}\cdots \\
\cdots\end{array}$ & $\begin{array}{r}2,89 * * * \\
(4.89)\end{array}$ & $\begin{array}{r}2.69 * * * \\
(18.02)\end{array}$ & $\begin{array}{r}3.69 * * * \\
(10.26)\end{array}$ \\
\hline CEFTA & $\begin{array}{l}\cdots \\
\cdots\end{array}$ & $\begin{array}{r}0,4823 * * * \\
(4.92)\end{array}$ & $\begin{array}{r}0.825 * * * \\
(9.65)\end{array}$ & $\begin{array}{r}1.521 * * * \\
(7.65)\end{array}$ \\
\hline Europe Agreements & $\begin{array}{l}\cdots \\
\cdots\end{array}$ & $\begin{array}{r}0.201 \\
(1.49)\end{array}$ & $\begin{array}{r}0.13 * * \\
(2.46)\end{array}$ & $\begin{array}{r}0.277 * * \\
(2.21)\end{array}$ \\
\hline EU preferential access to CEEC & $\begin{array}{l}\cdots \\
\ldots\end{array}$ & $\begin{array}{r}0,73 * * * \\
(5.52)\end{array}$ & $\begin{array}{c}0.67 * * * \\
(12.84)\end{array}$ & $\begin{array}{r}0.787 * * * \\
(6.37)\end{array}$ \\
\hline EU & $\begin{array}{l}\cdots \\
\ldots\end{array}$ & $\begin{array}{r}0,817 * * * \\
(6.06)\end{array}$ & $\begin{array}{r}0.531 * * * \\
(10.05)\end{array}$ & $\begin{array}{r}1.84 * * * \\
(16.20)\end{array}$ \\
\hline Ex-COMECON & $\begin{array}{l}\cdots \\
\cdots\end{array}$ & $\begin{array}{r}-0,442 * * * \\
(-3.54)\end{array}$ & $\begin{array}{r}-0.67 * * * \\
(-9.23)\end{array}$ & $\begin{array}{r}-0.245^{*} \\
(-1.66)\end{array}$ \\
\hline Border & $\begin{array}{l}\cdots \\
\cdots\end{array}$ & $\begin{array}{r}1,384 * * * \\
(8.97)\end{array}$ & $\begin{array}{r}1.234 * * * \\
(30.28)\end{array}$ & $\begin{array}{r}1.224 * * * \\
(10.68)\end{array}$ \\
\hline $\begin{array}{l}\mathrm{R}^{2} \\
\text { Hausman }\end{array}$ & $\begin{array}{r}0.41 \\
134.36\end{array}$ & 0.74 & 0.74 & 0.61 \\
\hline $\mathrm{LM}_{1}$ (cross-section effects) & $9,323.57$ & $\cdots$ & $\cdots$ & $\cdots$ \\
\hline $\mathrm{LM}_{2}$ (time effects) & 1.29 & $\ldots$ & $\ldots$ & $\ldots$ \\
\hline
\end{tabular}

Source: Estimates of authors.

Notes: BFTA denotes the Baltic Free Trade Area; CEFTA denotes the Central European Free Trade Area; EU denotes the European Union; CEEC denotes Central and Eastern European Countries; and COMECON denotes the Council for Mutual Economic Assistance. Numbers in parentheses indicate $t$ statistics, ${ }^{*}$ significant at $10 \%, * *$ significant at $5 \%, * * *$ significant at $1 \%$. 
Figure 1. Cross Sectional Estimated Parameter Values for Trade Agreements, 1996-2000
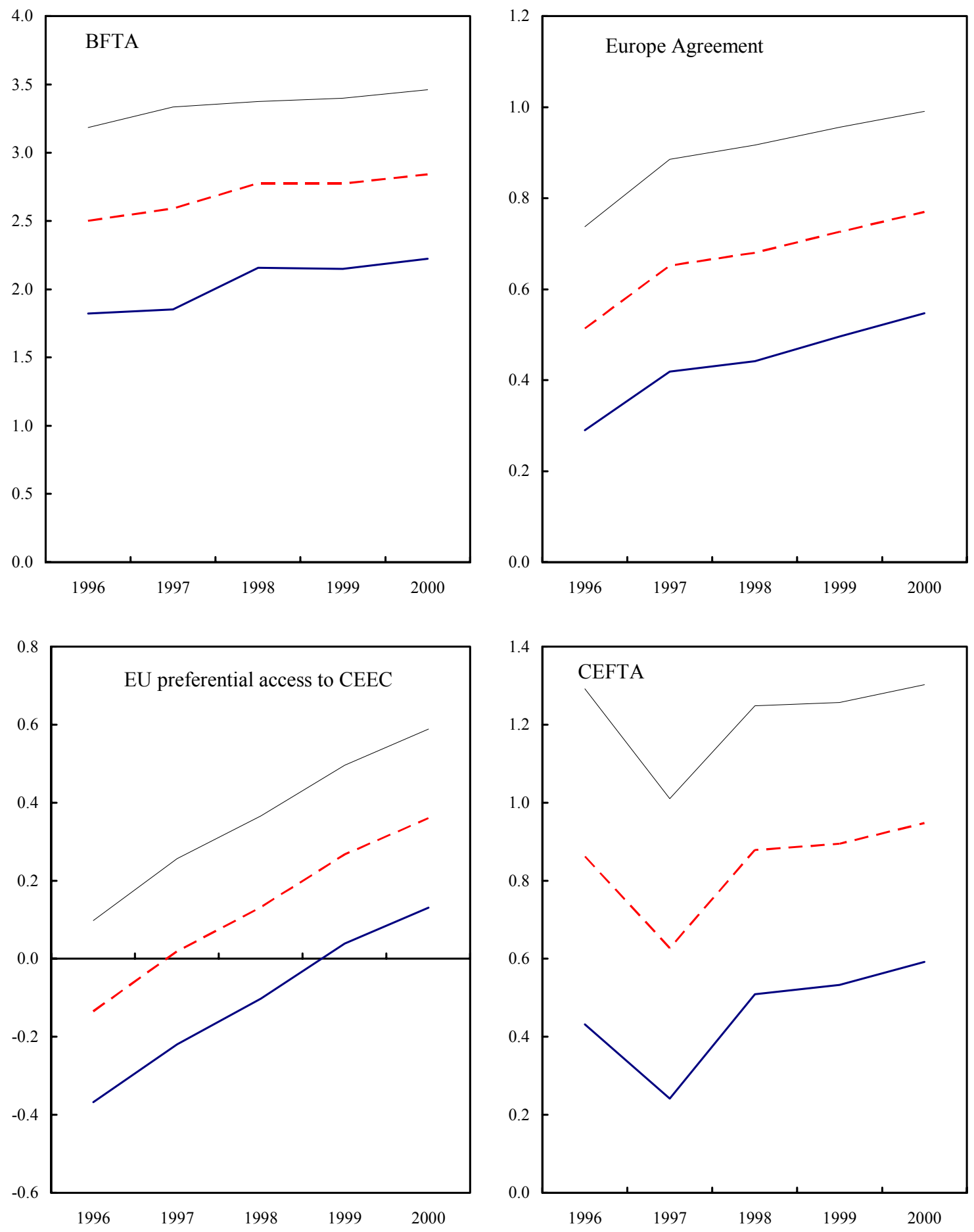

Source: Estimates of authors.

Notes: CEFTA denotes the Central European Free Trade Area; BFTA denotes the Baltic Free Trade Area; EU denotes the European Union.

1/ Intervals around the parameter value are confidence intervals at the 95 percent level of significance. 


\section{REFERENCES}

Adam, A., and T. Moutos, 2002, "The Political Economy of EU Enlargement or Why Japan Is Not A Candidate Country," CESifo Working Paper, No.704 (7).

Baldwin, R.E., 1993, “A Domino Theory of Regionalism,” NBER Working Paper No.4465.

— 1994, "Towards an Integrated Europe," CEPR, London.

— 1995, “The Eastern Enlargement of the European Union,” European Economic Review, (39), p. 474-481.

_ J. Francois and R. Portes, 1997, "The Costs and Benefits of Eastern Enlargement: The Impact on EU and Central Europe,” Economic Policy, (10), p.127-176.

Baltagi, B., 1995, “Econometric Analysis of Panel Data,” New York: John Wiley and Sons.

Byers, J.A., 1999, “Great Circle Distances,” available on the Internet at: http://www.wcrl.ars.usda.gov/cec/moregen.htm, Western Cotton Research Laboratory, Phoenix, AZ.

Choi, E. K., 2002, “Trade and the Adoption of a Universal Language," International Review of Economics and Finance, (11), p.265-275.

Christie, E., 2002, "Potential Trade in Southeast Europe: A Gravity Model Approach,” WIIW Working Papers No. 21.

Deardorff, A., 1995, “The Determinants of Bilateral Trade: Does Gravity Work In A NeoClassical World," NBER Working Paper, No. 5377, Cambridge, MA, and National Bureau of Economic Research.

Egger, P., 2000, "A Note On the Proper Econometric Specification of the Gravity Equation," Economics Letters, (66), p. 25-31.

Enders, A. and R. Wonnacott, 1996, “The Liberalization of East-West European Trade: Hubs, Spokes and Further Complications," The World Economy, Oxford.

Feldman, M., and R. Sally, 2002, "From the Soviet Union to the European Union: Estonian Trade Policy, 1991-2000," The World Economy, (2)5, p.79-106.

Hsiao, C., 1986, “Analysis of Panel Data,” Cambridge University Press, Cambridge, MA.

Hummels, D., and J. Levinsohn, 1995, "Monopolistic Competition and International Trade: Reconsidering the Evidence," Quarterly Journal of Economics, 110(3), p. 799-836. 
Kazlauskiene, N., and Meyers, W.H., 1999, “The Baltic Free-Trade Agreement In Agriculture: Early Results of the Experiment," MOCT-MOST, (9), p. 291-305.

Lavigne, M., 1995, “The Economics of Transition,” MacMillan: London.

Levy, P., 1997, “A Political Economy Analysis of Free-Trade Agreements,” American Economic Review, (87), p. 506-519.

Linder, S., 1961, “An Essay on Trade and Transformation,” New York: Wiley and Sons.

Mátyás, L., 1997, "Proper Econometric Specification of the Gravity Model," The World Economy, (20), p. 363-368.

, "The Gravity Model: Some Econometric Considerations," The World Economy, (21), p. 397-401.

McQueen, M., 2002, “The EU's Free-Trade Agreements with Developing Countries: A Case of Wishful Thinking?" The World Economy, (25), p. 1396-1385.

Messerlin, P., and P. Miroudot, 2003, "Trade-Liberalization in Southeast Europe: A First View on Eighteen FTAs," unpublished paper.

Michalopoulos, C., 2002, “A Strategy for Trade Integration In Southeast Europe: Accomplishments and Future Challenges," paper presented to the International Business Forum on Trade-Liberalization and Facilitation in Southeast Europe, Belgrade, October 7-8, 2002.

Paas, T., 2002, “Gravity Approach for Exploring Baltic Sea Regional Integration in the Field of International Trade," Hamburgisches Welt-Wirtschafts-Archiv (HWWA), Hamburg.

Polacheck, S.W., and Kim, M., 1994, "Panel Estimates of the Gender Earnings Gap: Individual-Specific Intercept and Individual-Specific Slope Models," (in Neuman, S., and Silber, J., (Eds.)). "The Econometrics of Labor Market Segregation and Discrimination," Journal of Econometrics, (61), p. 23-42.

Richardson, M., 1994, "Why A Free-Trade Area? The Tariff Also Rises,” Economics and Politics, (6), p.79-95.

Richter, S., 1998, “The CEFTA and the Europe Agreements,” MOCT-MOST, (8), p. 91-119.

Rudka, A., and K. Mizsei, 1994, "The Fall of Trade in East Central Europe: Is CEFTA the Right Solution?" Russian and East European Finance and Trade.

Wijkman, P. M., 2003, 'The Emergence of A Free-Trade Area in Southeastern Europe: the Economic Means to A Political End," conference paper presented to the Swedish Network for European Studies in Business and Economics, May 20-23, 2003. 